In cooperation with the Wisconsin Department of Natural Resources

\title{
Effects of Best-Management Practices in Otter Creek in the Sheboygan River Priority Watershed, Wisconsin, 1990-2002
}
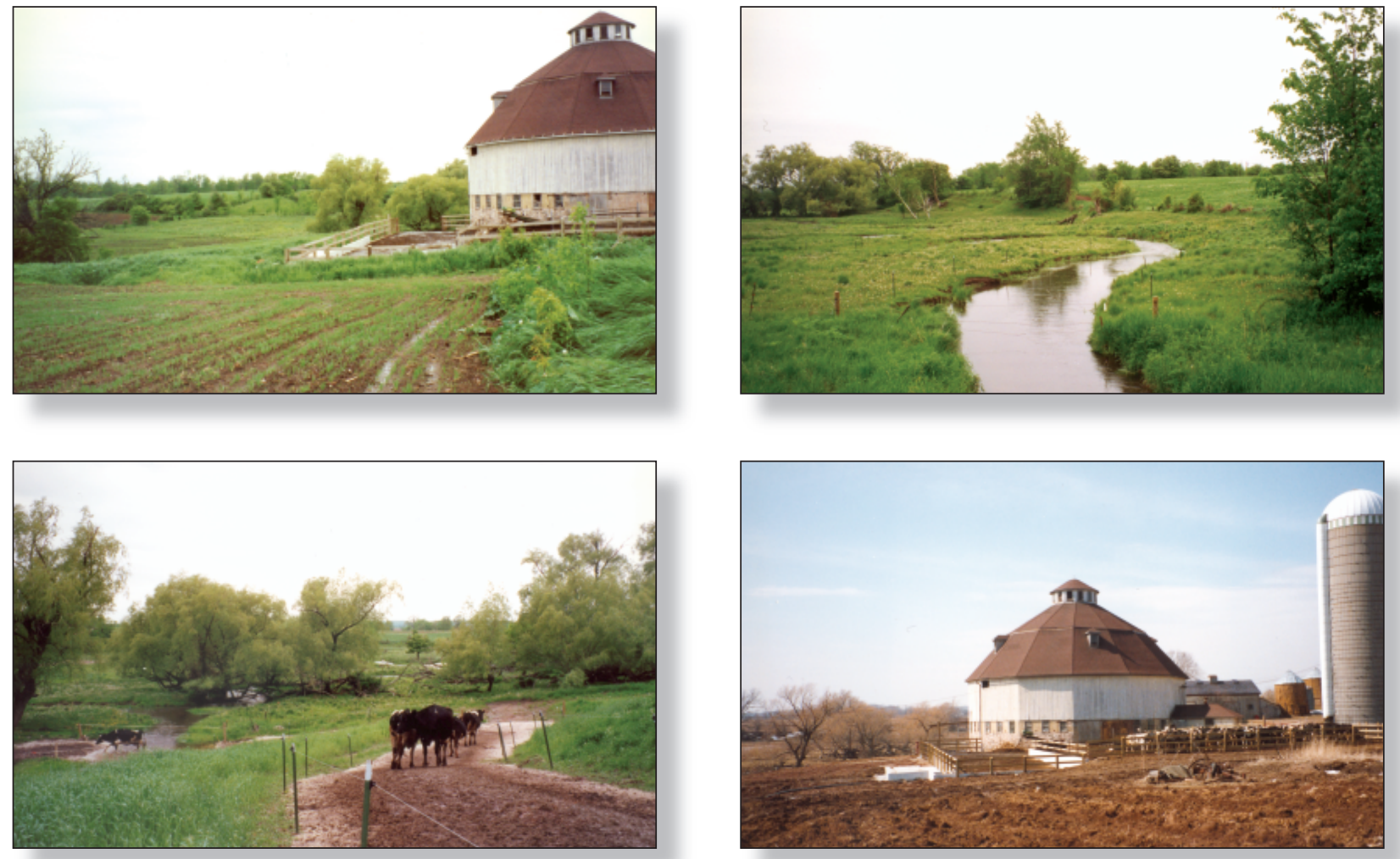

Scientific Investigations Report 2005-5009 


\section{Effects of Best-Management Practices in Otter Creek in the Sheboygan River Priority Watershed, Wisconsin, 1990-2002}

By Steven R. Corsi, John F. Walker, Lizhu Wang, Judy A. Horwatich, and Roger T. Bannerman

In cooperation with the Wisconsin Department of Natural Resources

Scientific Investigations Report 2005-5009 


\section{U.S. Department of the Interior \\ Gale A. Norton, Secretary \\ U.S. Geological Survey \\ Charles G. Groat, Director}

U.S. Geological Survey, Reston, Virginia: 2005

For sale by U.S. Geological Survey, Information Services
Box 25286, Denver Federal Center
Denver, CO 80225
For more information about the USGS and its products:
Telephone: 1-888-ASK-USGS
World Wide Web: http://www.usgs.gov/

Any use of trade, product, or firm names in this publication is for descriptive purposes only and does not imply endorsement by the U.S. Government.

\section{Cover photos (clockwise from top left):}

Barnyard runoff control system with vegetation

Streambank fencing on Otter Creek

Barnyard runoff control system without vegetation

Contained walkway and stream crossing 


\section{Contents}

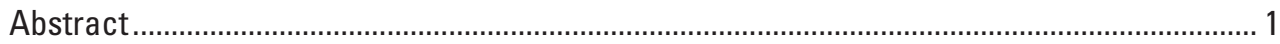

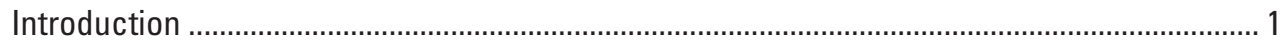

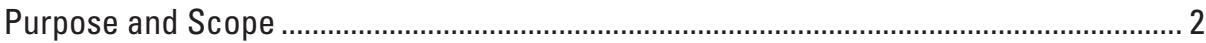

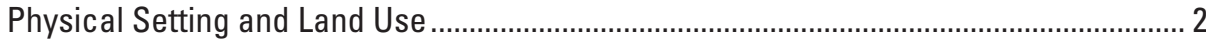

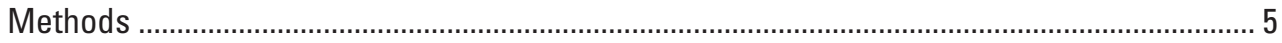

Hydrologic and Water Quality Data-Collection Network ............................................... 5

Biological Data Collection ................................................................................................. 5

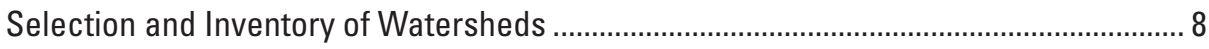

Hydrologic Conditions During the Study Period ........................................................................ 8

Water Quality Before and After Implementation of Best-Management Practices ................ 15

Constituent Concentrations at Base Flow ..................................................................... 15

Storm Loads ..................................................................................................................... 17

Biological Data Before and After Installation of Best-Management Practices ..................... 20

Effects of Management Practices on Otter Creek .................................................................... 21

Influence of BMPs on Water Quality............................................................................... 22

Influence of BMPs on Habitat and Fish ....................................................................... 23

Comparison of Results to Watershed Improvement Objectives .............................................. 23

Summary and Conclusions..................................................................................................... 24

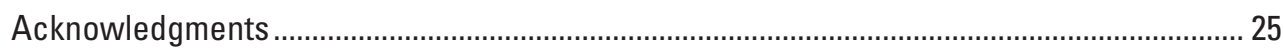

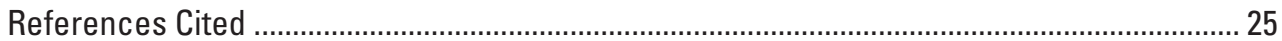




\section{Figures}

1-4. Maps showing:

1. Location of the Otter Creek, Meeme River, and Pigeon River Watersheds and data-collection sites in Sheboygan and Manitowoc counties, Wis.

2. Land use and land cover in the Otter Creek Watershed, Sheboygan County, Wis 4

3. Soil types in the Otter Creek Watershed, Sheboygan County, Wis. 6

4. Best-management practices implemented during the study period in the Otter Creek Watershed, Sheboygan County, Wis

5-11. Graphs showing:

5. Yearly precipitation throughout the study period and long-term average yearly precipitation at Plymouth and Sheboygan, Wis.

6. Cumulative rainfall distributions for the pre- and post-BMP (bestmanagement practices) implementation period at Otter Creek, Sheboygan County, Wis., for water years 1990-2002.

7. Annual streamflow, base flow, and stormflow at Otter Creek, Sheboygan County, Wis., for water years 1990-2002.

8. Average monthly distribution of streamflow and total suspended solids, total phosphorus, and dissolved ammonia nitrogen loads at Otter Creek, Sheboygan County, Wis., for water years 1990-2002.

9. Average relative annual contributions of stormflow and base-flow periods to streamflow, total suspended solids, total phosphorus, and dissolved ammonia nitrogen loadings at Otter Creek, Sheboygan County, Wis., for water years 1990-2002.

10. Average monthly streamflow and loads of total suspended solids, total phosphorus, and dissolved ammonia nitrogen during base flow and stormflow periods, expressed as a percentage of the annual total water volume and constituent loads at Otter Creek, Sheboygan County, Wis.

11. Concentrations and water-year medians of total suspended solids, total phosphorus, dissolved ammonia nitrogen, biochemical oxygen demand, and fecal coliform in base-flow samples throughout the study period at Otter Creek, Sheboygan County, Wis. 


\section{Tables}

1. Summary of targeted and implemented rural best-management practices in the Otter Creek watershed, Sheboygan County, Wis...

2. Results of Wilcoxon rank-sum test for differences between constituent concentrations in base-flow samples from pre- and post-BMP implementation periods at Otter Creek, Sheboygan County, Wis.

3. Regression results for storm loads from rainfall periods at Otter Creek, Wis., for combined and separate seasons

4. Median rainfall-period storm loads and results of the Wilcoxon rank-sum test comparing storm-load residuals for pre- and post-BMP periods at 0 tter Creek, Wis.

5. Average percent reductions predicted across all monitored storms by use of pre- and post-BMP regressions to estimate loads from rainfall periods at Otter Creek, Wis.

6. Results of trend analysis comparing habitat for pre- and post-BMP periods using analysis of covariance with the treatment station and reference stations, Otter Creek, Meeme River, and Pigeon River, Wis.

7. Results of trend analysis comparing fish community data for pre-and post-BMP periods using analysis of covariance with the treatment station and reference stations, Otter Creek, Meeme River, and Pigeon River, Wis. 


\section{Conversion Factors and Abbreviations}

\begin{tabular}{lcl}
\hline Multiply & By & To obtain \\
\hline \multicolumn{3}{c}{ Length } \\
\hline inch (in.) & 25.4 & millimeter $(\mathrm{mm})$ \\
foot (ft) & 0.3048 & meter $(\mathrm{m})$ \\
mile (mi) & 1.609 & kilometer $(\mathrm{km})$ \\
\hline \multicolumn{3}{c}{ Area } \\
\hline acre & 0.4047 & square hectometer $\left(\mathrm{hm}^{2}\right)$ \\
square mile $\left(\mathrm{mi}^{2}\right)$ & 2.590 & square kilometer $\left(\mathrm{km}^{2}\right)$ \\
\hline \multicolumn{3}{c}{ Flow rate } \\
\hline cubic foot per second $\left(\mathrm{ft}{ }^{3} / \mathrm{s}\right)$ & 0.02832 & \\
\hline pound, avoidupois $(\mathrm{lb})$ & Mass & \\
ton per day (ton $/ \mathrm{d})$ & 0.4536 & kilogram $(\mathrm{kg})$ \\
& 0.9072 & metric ton per day \\
\hline foot per mile $(\mathrm{ft} / \mathrm{mi})$ & Hydraulic gradient & \\
\hline
\end{tabular}

Temperature in degrees Celsius $\left({ }^{\circ} \mathrm{C}\right) \mathrm{can}$ be converted to degrees Fahrenheit $\left({ }^{\circ} \mathrm{F}\right)$ as follows:

$$
{ }^{\circ} \mathrm{F}=\left[1.8 \mathrm{x}^{\circ} \mathrm{C}\right]+32 .
$$

Concentrations of chemical constituents in water are given in milligrams per liter (mg/L). 


\title{
Effects of Best-Management Practices in Otter Creek in the Sheboygan River Priority Watershed, Wisconsin, 1990-2002
}

\author{
By Steven R. Corsi', John F. Walker', Lizhu Wang², Judy A. Horwatich', and Roger T. Bannerman²
}

\section{Abstract}

The U.S. Geological Survey and the Wisconsin Department of Natural Resources began a comprehensive, multidisciplinary evaluation-monitoring program in 1989 to assess the effectiveness of the Wisconsin Nonpoint Source Program. Hydrologic, water-quality, habitat, and fish data were collected at Otter Creek from 1990 to 2002 with the pre-BMP (best-management practice) period ending in September 1993 and the post-BMP period beginning in October 1999. BMPs installed in this basin included streambank protection and fencing, stream crossings, grade stabilization, buffer strips, various barnyard-runoff controls, nutrient management, and a low degree of upland BMPs. Reductions between pre- and post-BMP periods were detected in median concentrations of base-flow samples for total suspended solids and BOD5 but not for total phosphorus or dissolved ammonia nitrogen; fecal coliform concentrations in base-flow samples increased over the study period.

Reductions in rainfall storm loads between the preand post-BMP periods during the non-vegetative season (November through May) were detected for all three constituents monitored (total suspended solids, total phosphorus, and dissolved ammonia nitrogen). Differences in rainfall storm loads of these three constituents for the vegetative season (June through October) were not detected. When considering rainfall data from the entire year, reductions in storm loads were detected for total suspended solids and dissolved ammonia nitrogen (reductions were estimated at 58 percent for total suspended solids and 41 percent for dissolved ammonia nitrogen). Annual reduc-

${ }^{1}$ U.S. Geological Survey, Middleton, Wisconsin

${ }^{2}$ Wisconsin Department of Natural Resources, Madison, Wisconsin tions in rainfall storm loads for the non-vegetative season were estimated at 58 percent for total suspended solids, 48 percent for total phosphorus, and 41 percent for dissolved ammonia nitrogen.

Habitat and fish data were collected each year of the study to track the effects of BMPs on stream habitat and fish communities. Final trend analysis was performed using habitat quality index scores, an index of biotic integrity, and some of the originally measured fish and habitat variables. Habitat was improved for stream segments that had either natural riparian buffer or where streambank fencing was installed, but not at the station where the riparian area was pasture and no streambank fencing was installed. The results also suggest that BMP implementation in Otter Creek substantially modified fish community structure, but the overall community quality was not improved.

\section{Introduction}

Nonpoint-source contamination is a major contributor to water-resource-quality problems in Wisconsin. In recognition of the importance of nonpoint sources, the Wisconsin Nonpoint Source Water Pollution Abatement Program (Nonpoint Program) was enacted in 1978. When first introduced, the Nonpoint Program identified problems in 130 of the 330 watersheds in Wisconsin. For a given watershed, various management options - termed bestmanagement practices (BMPs) - are available for funding support through the Nonpoint Program. For example, practices in rural areas include conservation tillage, contour strip-cropping, streambank protection, and various barnyard-runoff controls. The Nonpoint Program provides matching funds to landowners for voluntary implementation of various BMPs using priority watersheds as a unit for consideration. 
Until the late 1980 s, very little data existed to demonstrate the effectiveness of BMPs for improving water quality in Wisconsin's priority watersheds. The Wisconsin Department of Natural Resources (WDNR) and U.S. Geological Survey (USGS) developed and began a comprehensive, multidisciplinary evaluation-monitoring program in water year 1989 to assess the effectiveness of the Wisconsin Nonpoint Source Program (Wierl and others, 1996). This evaluation-monitoring program includes biological and stream-habitat monitoring by the WDNR and waterquality monitoring by the USGS. Eight watersheds were chosen for the evaluation-monitoring program. Results from two of these watersheds, Brewery and Garfoot Creeks in the Black Earth Creek Watershed, were published previously (Graczyk and others, 2003). This report presents results from Otter Creek, the third watershed where evaluation monitoring has been completed. These watersheds were chosen because WDNR and Land County Conservation District personnel felt that there existed a potential for significant improvement and because BMPs were scheduled to be installed within the project time frame.

The USGS, in cooperation with the WDNR, studied the Otter Creek Watershed, a subbasin of the Sheboygan River, in eastern Wisconsin from September 1990 through September 2002 to assess the hydrology, biology, habitat, and water quality of Otter Creek and its tributaries. Streamflow and water-quality data were collected continuously at one station near the mouth of Otter Creek, while biology and habitat data were collected annually at four stations.

\section{Purpose and Scope}

This report summarizes the results of a study on effectiveness of watershed-management practices for controlling nonpoint-source contamination in the Otter Creek Watershed. Concentrations of total suspended solids, total phosphorus, dissolved ammonia nitrogen, 5-day biochemical oxygen demand $\left(\mathrm{BOD}_{5}\right)$, and fecal coliform in samples collected at base flow before BMP installation (pre-BMP) are compared and contrasted to those for the period after BMP installation (post-BMP). Pre-BMP storm loads of total suspended solids, total phosphorus, and dissolved ammonia nitrogen from sampled rainfall periods are compared and contrasted to the post-BMP storm loads. In addition, fish and habitat data are compared and contrasted between pre-BMP periods and post-BMP periods.

Data collection began in September 1990 and continued until September 2002. From September 1990 through September 30, 1993, BMPs were not installed in the Otter Creek watershed, and this time period is considered to be the pre-BMP period. Installation of BMPs began in 1993. In October 1999, BMP installation that was planned for this program was complete in the watershed. Monitoring after this time was considered to be the post-implementation period. For the purpose of this study, the post-BMP period is considered to be October 1999 through September 2002.

The overall objective of the WDNR and USGS evaluation-monitoring program was to evaluate BMP effectiveness in several small watersheds located in geographically and hydrologically diverse areas of Wisconsin.

\section{Physical Setting and Land Use}

Otter Creek is a tributary to the Sheboygan River in Sheboygan County about 4 mi northeast of the city of Plymouth, Wis. (fig. 1). Otter Creek has been classified by the WDNR as a warm-water forage stream that has the potential to maintain a forage fish population and is suitable for partial body contact for recreational purposes (Wisconsin Department of Natural Resources, 1993).

Otter Creek drains $9.5 \mathrm{mi}^{2}$ upstream from the streamgaging station near Plymouth, and the total stream length, including perennial and intermittent channels, is $13.0 \mathrm{mi}$ from the station to the stream headwaters. The watershed contains several small lakes and ponds. The stream flows directly through two of the small lakes (first through Little Gerber Lake, then through Big Gerber Lake), which are connected by a short channel. These lakes are 7 acres and 15 acres in surface area and have a maximum of 21 and $37 \mathrm{ft}$ in depth, respectively. The overall channel slope of Otter Creek is $25 \mathrm{ft} / \mathrm{mi}$, and the channel slope between the 10- and 85-percent points for the main channel is $23 \mathrm{ft} / \mathrm{mi}$. The bed material consists mainly of sand, silt, and clay with gravel in riffle areas. The Otter Creek watershed has level to nearly level land slopes, a result of glacial scouring of the landscape.

Total land use and land cover for Otter Creek is shown in figure 2. In the Otter Creek Watershed, cropland (62 percent) dominates the land use and land cover, with woodlots (14 percent) being the next greatest land use and land cover. Other substantial land use and land cover in Otter Creek includes grassland (10 percent) and wetlands ( 6 percent). In all, 64 farms are included in the Otter Creek Watershed. The average farm size is 140 acres, with an average of 129 acres in crop production. There are eight barnyards in the watershed with an average herd size of 45 animals, all of which are dairy cows (Rappold and others, 1997). According to the Sheboygan County Land and Water Conservation Department, the number of livestock in the watershed and the cropland percentage has not changed substantially 

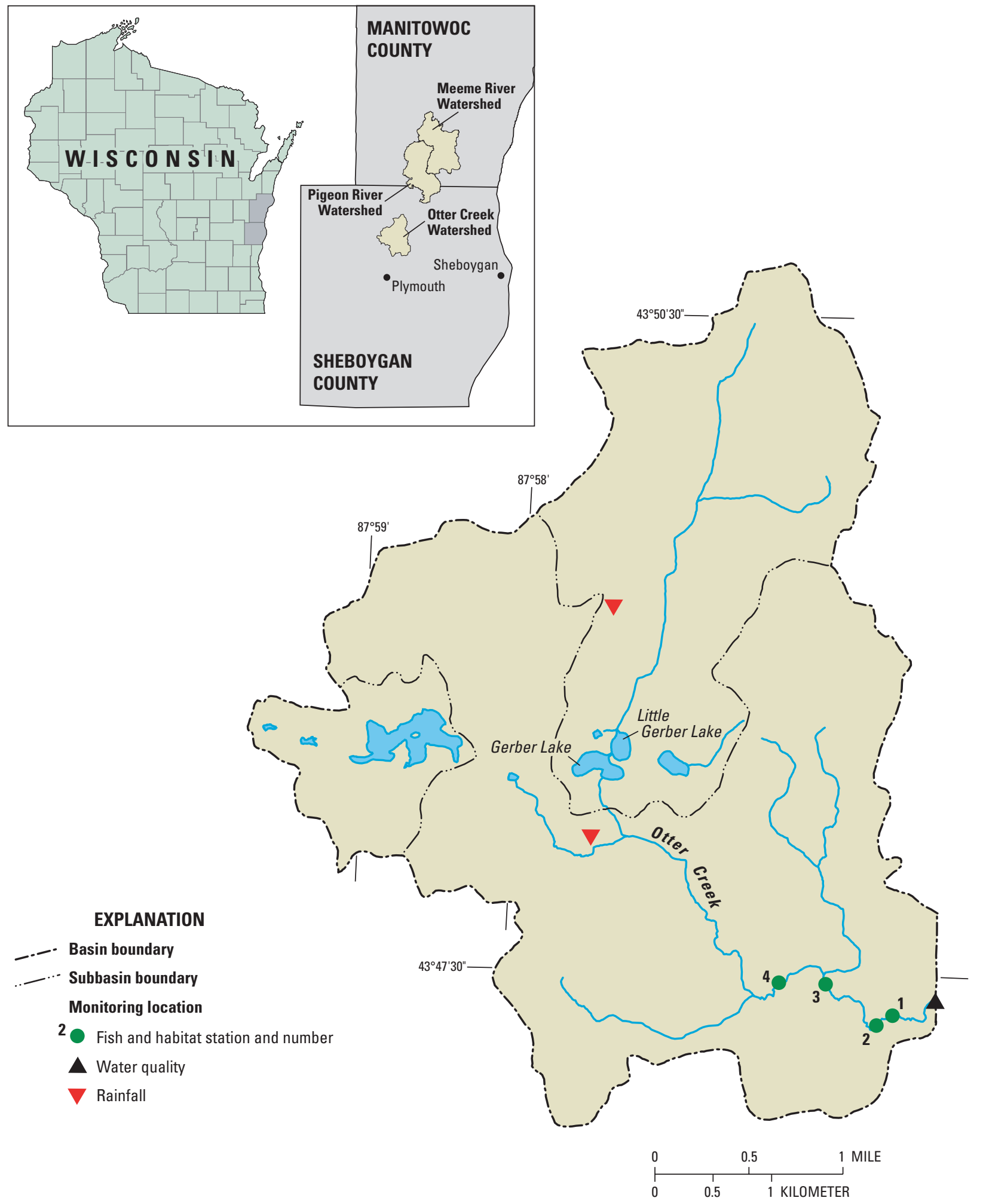

Figure 1. Location of the Otter Creek, Meeme River, and Pigeon River Watersheds and data-collection sites in Sheboygan and Manitowoc counties, Wis. 


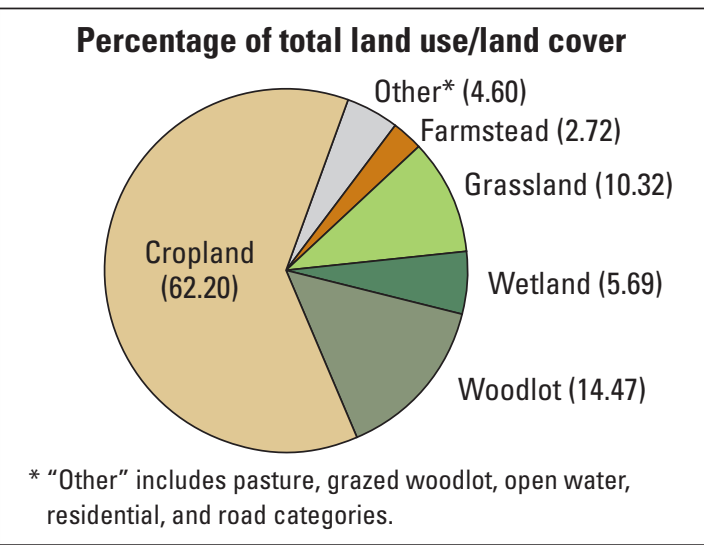

\section{EXPLANATION}

Land use/land cover type

\begin{tabular}{|c|}
\hline Cropland \\
\hline Pasture \\
\hline Grassland \\
\hline Woodlot \\
\hline Grazed wood \\
\hline Open water \\
\hline Wetland \\
\hline Farmstead \\
\hline Residential \\
\hline Road \\
\hline
\end{tabular}

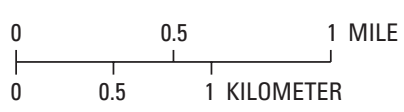

Land use/land cover interpreted from

Sheboygan County 1:4800 orthophotos, 1990.

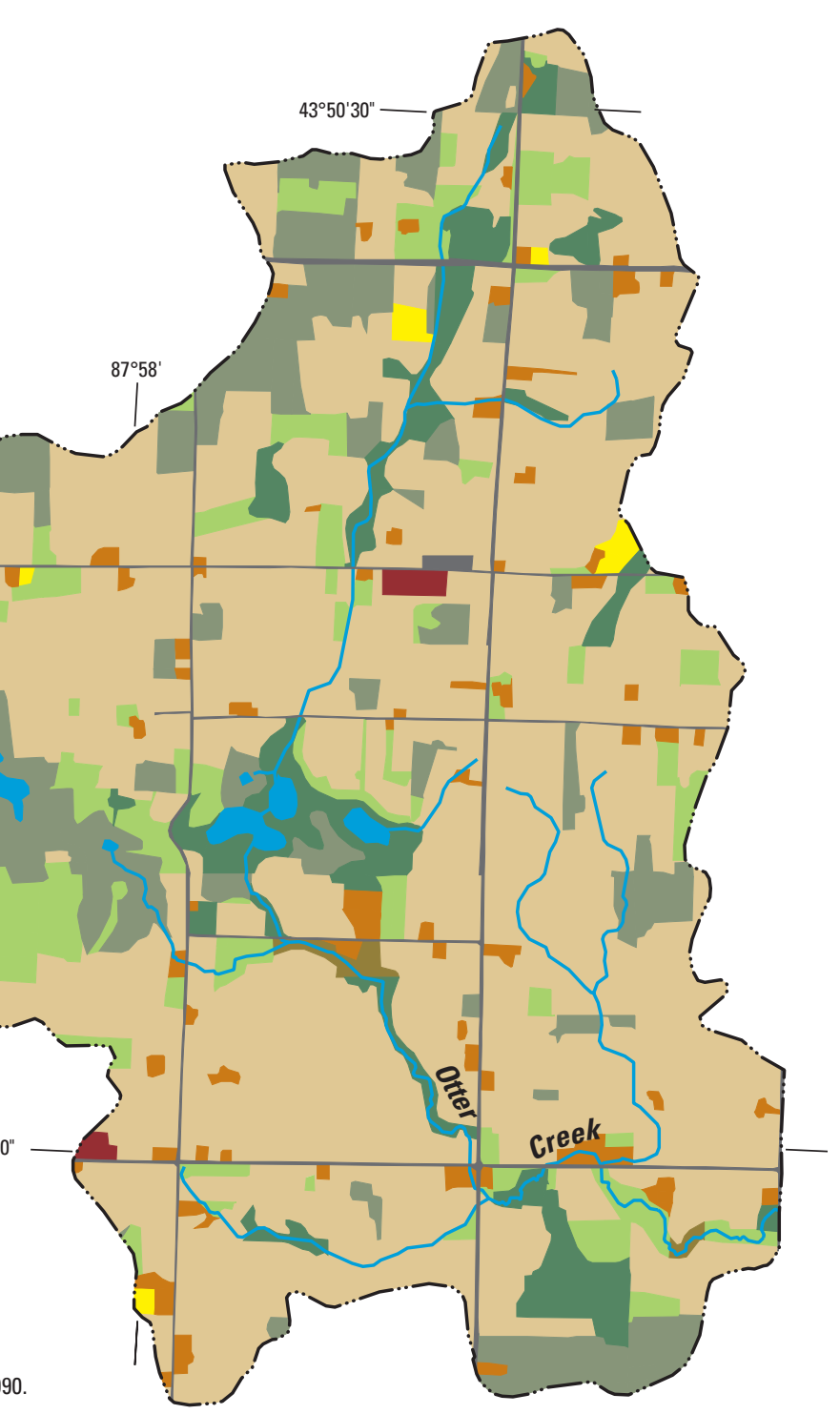

Figure 2. Land use and land cover in the Otter Creek Watershed, Sheboygan County, Wis. 
throughout the monitoring period, but exact numbers were not available. The soil types in the Otter Creek watershed vary spatially and consist mainly of silt loams to silty clay loams (fig. 3). These soils are well drained to somewhat poorly drained (Engel and others, 1978).

\section{Methods}

Watersheds can be affected in numerous ways by changes in land use and land management brought about by BMP installation. A suite of different variables were considered in an attempt to understand these effects. Hydrologic, water-quality, habitat, fish, and land-use data were the areas of study considered to be important for this evaluation. Not only are the areas of study important in this evaluation, but the exact methods of data collection and analysis are essential in detecting changes resulting from BMP installation. A description of data collection and analysis methods for each of these areas of study are included in this section.

\section{Hydrologic and Water Quality Data- Collection Network}

A stream-gaging station equipped for continuous recording of data was installed in September 1990 at Otter Creek (fig. 1). Stage was measured with bubbler-type pressure transducers every 5 minutes during periods of increased runoff and every hour otherwise. Streamflow measurements were made according to standard USGS methods (Rantz and others, 1982) every 4 to 6 weeks, and more frequently during high flows, to define the stagestreamflow relation used to compute continuous streamflow record.

The gaging station was equipped with a stage-activated refrigerated water sampler for automatic collection of water samples during periods of increased runoff from rainfall or snowmelt. The data logger was programmed to initiate sampling once the stream stage reached an initial sampling threshold. As stage increased, samples were collected with each 0.2 -ft increase in stage; as stage decreased, samples were collected with each $0.3-\mathrm{ft}$ decrease in stage. The sampling strategy was designed to collect more samples during increasing stage, when the concentration of the constituents of interest would likely be changing most rapidly. After a sampling event, the samples were collected from the gaging station, chilled on ice in coolers, processed at the USGS field office, and then transported to the Wisconsin State Laboratory of Hygiene to be analyzed for total suspended solids, total phosphorus, dissolved ammonia nitrogen, $\mathrm{BOD}_{5}$, and fecal coliform, using standard methods (Wisconsin State Laboratory of Hygiene, 1992, American Public Health Association, 1989, 1992). Samples collected were selected for analysis to represent variation in water quality over a range of increasing and decreasing stages.

In addition to the automated samples, manual samples were collected at a fixed interval. The fixed interval from the beginning of the study to August 1994 was approximately every 2 weeks in the spring, summer, and fall and once a month in the winter. After August 1994, the fixed interval was changed to weekly from April through October, twice per month in March and November, and monthly from December through February. Samples were integrated over the depth and width of the stream by use of a hand-held sampler (Edwards and Glysson, 1988). The fixed-interval samples also were analyzed for total suspended solids, total phosphorus, dissolved ammonia nitrogen, biochemical oxygen demand, and fecal coliform.

Precipitation was measured throughout the study period at three locations within the watershed (fig. 1). One rain gage was at the stream-gage location, and the other two rain gages were sited by trial and error to result in approximately equal Thiessen polygon areas. Thiessen polygons represent the areas in closest proximity to each rain gage; the average precipitation was computed as a weighted average using the Thiessen polygon areas as the weighting factor (Viessman and others, 1977). Precipitation was collected in an 8-in. collector that drained into a tipping bucket rain gage. Each tip represented 0.01 in. of rain; all rainfall data were recorded every 5 minutes. Rain gages were calibrated annually.

\section{Biological Data Collection}

Habitat and fish data were collected from Otter Creek and two reference streams. The reference watersheds were chosen to have similar characteristics in elevation, climate, surficial geology, soil, streamflow and temperature regimes, stream size, and stream segment gradient. Without human influence, Otter Creek and the reference streams would be expected to have similar water quality, physical habitat, and biological communities.

Four sampling stations were established in the lower segment of the Otter Creek Watershed to monitor the effects of watershed BMP implementation on habitat and fish (fig. 1). Stations 1, 3, and 4 were located in heavily grazed pasture areas where the cattle had free access to the stream and the streambanks were severely trampled. 


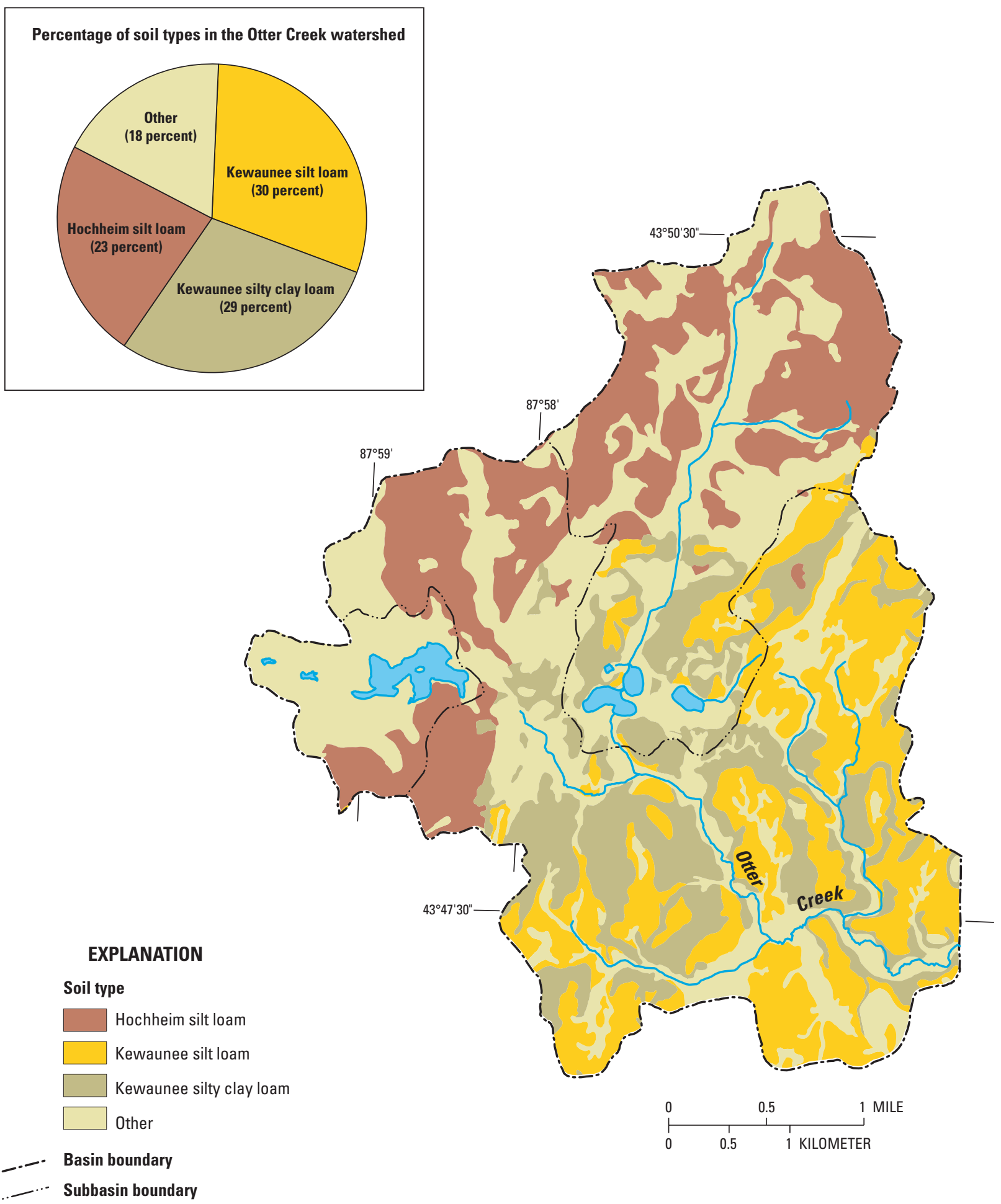

Figure 3. Soil types in the Otter Creek Watershed, Sheboygan County, Wis. 
Station 3 was adjacent to a large barnyard that appeared to be a source of manure during runoff events. Station 2 was between stations 1 and 3 in a wooded riparian section of the stream. The streambanks along stations 1 and 3 were fenced in 1993 and 1996, respectively, to keep livestock off the streambanks and out of the stream. Station 4 was upstream from the other stations, and streambank fencing was not installed.

The reference streams, Meeme River and Pigeon River, drain $17.8 \mathrm{mi}^{2}$ and $14.7 \mathrm{mi}^{2}$, respectively, at the furthest downstream sampling stations. Geographically, the reference watersheds are within 12 miles of Otter Creek. Meeme River is a tributary of the Pigeon River, which is tributary to Lake Michigan. Soil types in both reference watersheds are largely loams and silt loams as are soil types in the test stream. Both Meeme River and Pigeon River are third order, low gradient (5.8-14.8 ft/mi), warmwater streams. The Meeme and Pigeon Rivers have slightly higher proportions of agricultural land use (80 and 71 percent) and lower percentages of vegetative land (12 and 18 percent) in their watersheds compared with Otter Creek (the treatment stream). The riparian area for the Pigeon River was pasture for station 1 and narrow shrub buffer for station 2. The riparian area for the Meeme River was grass and shrub buffer. Both reference streams had barnyards in the upland of their watersheds. Two stations were sampled on each of the reference streams. There were no substantial land-use changes in the reference watersheds during the study years.

Sampling was done between July 30 and September 11 each year when low streamflow facilitated sampling effectiveness and large-scale fish movement was unlikely (Lyons and Kanehl, 1993). Not all stations were sampled during each year, because a small number of stations were sampled in the initial years and more sampling stations were added as more resources became available in subsequent years. For Otter Creek, one station was sampled in 1990, two stations were sampled in 1991, and all four stations were sampled from 1992 to 2002. For the reference streams, one station was sampled between 1990 and 1993, and two stations on each stream were sampled from 1994 to 2002.

Sampling station length was 35 times the mean stream width or a minimum of $328 \mathrm{ft}$, a distance sufficient to characterize the fish assemblage and to encompass about three meander sequences of the stream channel (Lyons, 1992; Simonson and others, 1994). Actual station lengths ranged from 344 to $768 \mathrm{ft}$.

Various habitat variables were assessed at the sampling stations. Water turbidity, dissolved oxygen, specific conductance, and flow were measured at the downstream end of the station. Lengths of runs, riffles, and pools and the mean distances between bends and between riffles were determined for the entire station. Thirty habitat variables, encompassing channel morphology, bottom substrates, cover for fish, bank conditions, riparian vegetation, and land use were measured or visually estimated along 12 evenly spaced transects by means of standardized procedures (Simonson and others, 1994).

Fish sampling, consisting of a single upstream pass without block nets, was done within a day of habitat assessment. The entire length of each station was electrofished with a single tow-barge unit (Lyons and Kanehl, 1993; Simonson and Lyons, 1995). During sampling, efforts were made to collect all fish greater than or equal to 0.98 in. in total length observed, and all captured fish were identified to species, counted, weighted in species aggregates, and released back to the stream.

Habitat data were summarized by calculating the mean and variance for each variable for each station in each year. From these variables, wetted-stream widthdepth ratio and habitat-quality index scores were computed by use of a system developed for Wisconsin stream fishes (Simonson and others, 1994). The overall habitat score was the sum of differentially weighted scores for the quality of riparian buffers, bank erosion, pool area, width-depth ratio, distance between riffles or bends, amount of fine sediment on the bottom, and cover for fish.

To summarize the fish data, computations were done for fish density (number per $328 \mathrm{ft}$ of stream length) and percentages of individuals that were omnivores, insectivores, carnivores, simple lithophils, and tolerant and intolerant of environmental degradation (Lyons, 1996). Fish data were then used to compute an index of biotic integrity (IBI). The IBI applied here was specifically developed for Wisconsin warm-water streams and could range from 0 to 100 , with higher values indicating more environmentally sensitive fish communities (Lyons, 1996).

To evaluate how stream habitat and fish community changed through study years and how these variables responded to the implementation of BMPs, an analysis of covariance (ANCOVA) was done with reference data as covariance to isolate the effects of BMPs on habitat and fish from the effects of other factors, such as temporal climate changes that might have caused natural variation of stream habitat and fish communities. The ANCOVA, done by use of SAS (SAS institute Inc., 1990), is a type of multiple linear regression in which the relations of habitat and fish variables between reference and treatment streams were tested over time (Grabow and others, 1999). 


\section{Selection and Inventory of Watersheds}

Inventory of the rural watersheds began in 1992 to provide information on land-use and land-treatment changes that may affect water quality. A geographic information system (GIS) database contained the land-use and BMP inventories. Watershed boundaries, hydrography, roads, streams, woodlots, rain gages, and BMPs were digitized from 1:24,000 topographic maps. Farm-field and parcel mapping was done by the USGS staff by digitizing orthophotos. Detailed descriptions of each watershed and the BMP program were reported in Rappold and others (1997), and Wierl and others (1996).

The Priority Watersheds Program selected, assessed, and approved the Sheboygan River project between 1985 and 1991. Otter Creek is in the Sheboygan River Watershed and was administered under the Sheboygan River Priority Watershed project. Voluntary sign-up period for BMPs started in March 1989 and lasted until March 1997. Monitoring of the post-BMP implementation began on October 1, 1999, after the majority of practices were installed and operational.

Targeted and implemented BMPs for the Otter Creek Watershed are summarized in table 1. Annual updates of practices-animal-waste management, streambank protection, and upland management - were obtained by contacting the Sheboygan County Land Conservation Department. Animal-waste management systems are installed to reduce the amount of organic matter reaching the stream by improving the cattle lots and adding filter strips. Streambank protection reduces the amount of sediment reaching the stream by limiting cattle access and stabilizing streambanks by various practices, including fencing and installation of watering areas in the stream. Upland-management practices reduce the amount of sediment and phosphorus by cropland and manure management on highly erodible lands. Upland-control practices include change in crop rotation, reduced tillage, critical area stabilization, grass waterways, and pasture management.

In 1999, a majority of the BMP installation goals set by the WDNR and local Land Conservation Department had been achieved in the Otter Creek Watershed. Additional practices could be implemented for several years, but it was felt that many sources of nonpoint pollution had been controlled by the practices that had been implemented and there were no immediate plans to implement more BMPs for sources that were not controlled. The land-use tracking was discontinued in 2002 when the postBMP monitoring phase ended. The status of barnyard and streambank-protection practices as of 2002 is shown in figure 4 .
Table 1. Summary of targeted and implemented rural bestmanagement practices in the Otter Creek watershed, Sheboygan County, Wis.

[BMP, best-management practice]

\begin{tabular}{|c|c|c|}
\hline Management practice & Targeted & Implemented \\
\hline \multicolumn{3}{|c|}{ Animal-waste management } \\
\hline Manure storage (facilities) & 4 & 3 \\
\hline $\begin{array}{l}\text { Barnyard-runoff control } \\
\text { systems (facilities) }\end{array}$ & 8 & 8 \\
\hline $\begin{array}{l}\text { Milkhouse wastewater } \\
\text { treatment (facilities) }\end{array}$ & 0 & 2 \\
\hline \multicolumn{3}{|c|}{ Streambank protection } \\
\hline Streambank protection (feet) & 6,600 & 6,220 \\
\hline Fencing (feet) & 9,200 & 9,200 \\
\hline $\begin{array}{l}\text { Stream crossings } \\
\quad \text { (number of crossings) }\end{array}$ & 5 & 2 \\
\hline $\begin{array}{l}\text { Grade stabilization } \\
\quad \text { (structures) }\end{array}$ & 4 & 4 \\
\hline Buffer strips (acres) & 0 & 19.76 \\
\hline \multicolumn{3}{|c|}{ Upland management } \\
\hline $\begin{array}{l}\text { Targeted nutrient } \\
\text { management (acres) }\end{array}$ & 1,130 & 1,570 \\
\hline $\begin{array}{l}\text { Targeted upland BMPs (tons } \\
\text { of sediment) }\end{array}$ & 505 & 276 \\
\hline
\end{tabular}

${ }^{1}$ Upland BMPs include change in crop rotation, reduced tillage, critical area stabilization, grass waterways, and pasture management.

Wisconsin's administrative rules to address the control of polluted runoff from rural areas are specified in NR120, "The Priority Watershed and Priority Lake Program". The rules identify the most effective BMPs to control nonpoint pollutants. Those practices identified could be cost-shared up to 70 percent by the State of Wisconsin. The approximated cost for installation of BMPs in the Otter Creek Watershed was $\$ 675,000$. About 60 percent of this funding was for animal-waste management practices, 35 percent was for streambank practices and 5 percent for upland-management practices. It should be noted that most of the streambank buffering of Otter Creek was not funded by this program but rather by outside sources.

\section{Hydrologic Conditions During the Study Period}

Precipitation: The 30-year normal annual precipitation is 36.3 in. at the National Oceanic and Atmospheric Administration (NOAA) weather station in Plymouth, Wis., and 31.9 in. at the NOAA weather station in Sheboygan, Wis. (National Oceanic and Atmospheric 


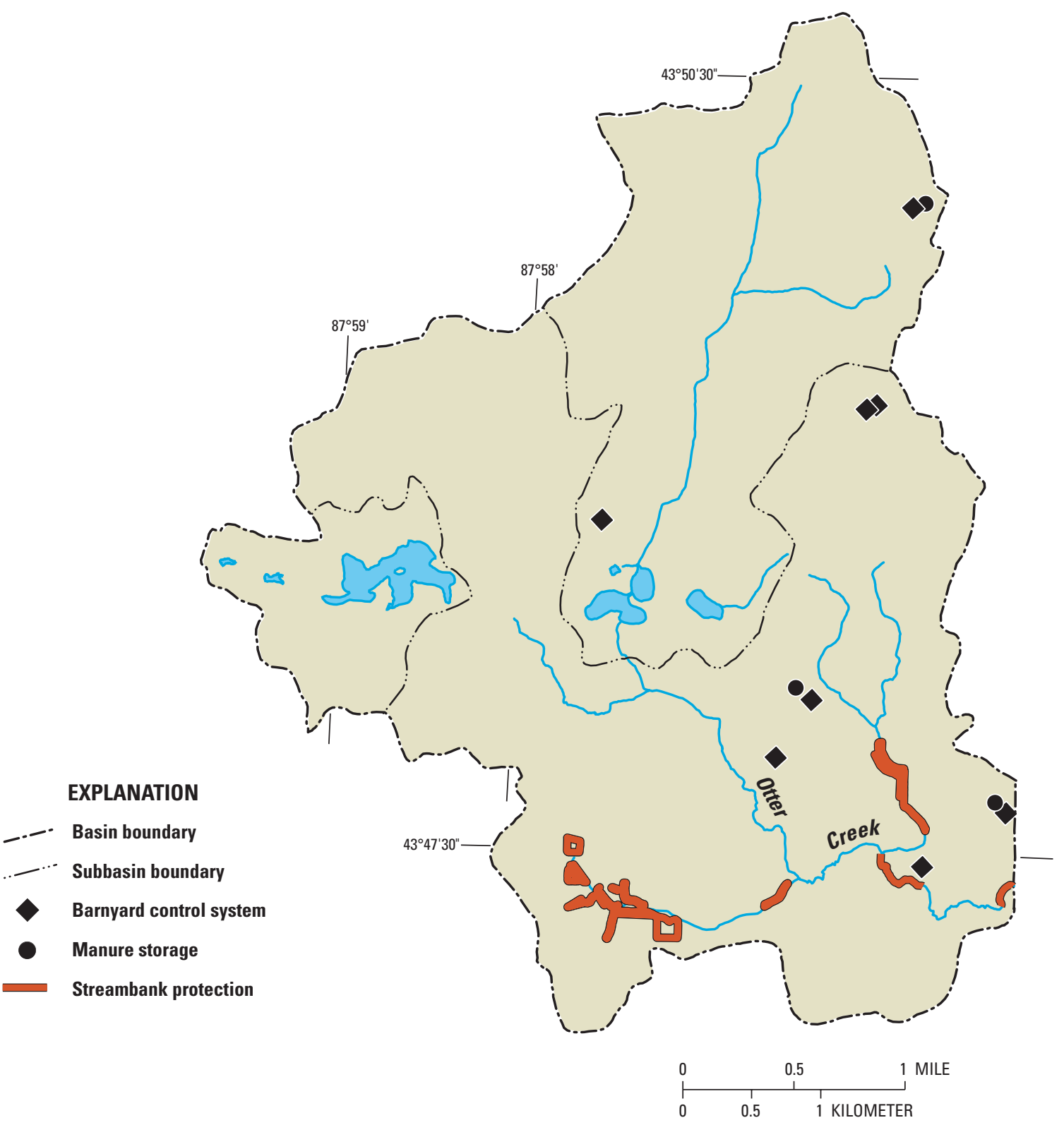

Figure 4. Best-management practices implemented during the study period in the Otter Creek Watershed, Sheboygan County, Wis.

Administration, 2000). Long term averages are $31.8 \mathrm{in.}$ at Plymouth (1910 through 2002) and 30.8 in. at Sheboygan (1899 through 2002). Data collected at the NOAA gages indicate that precipitation during the study period was less than the long-term average for two of three years during the pre-BMP implementation phase and one of three years during the post-BMP implementation phase of the study (fig. 5). The largest deviation between annual precipitation and the long-term average was in calendar year 2000,

when the precipitation was $42.6 \mathrm{in}$. at Sheboygan and 35.1 in. at Plymouth.
Monitored storms during the study period ranged in precipitation depth from 0.21 to $3.52 \mathrm{in}$. The median depth of precipitation from the monitored storms was greater during the pre-BMP implementation period (1.02 in.) than during the post-BMP implementation period ( 0.83 in.). The distribution of precipitation depth from monitored storms during the pre-BMP implementation period also indicates that the pre-BMP implementation-period storm depths were greater than those from the post-BMP implementation period (fig. 6).

Streamflow: Streamflow data were collected continuously during the entire study period and published each 


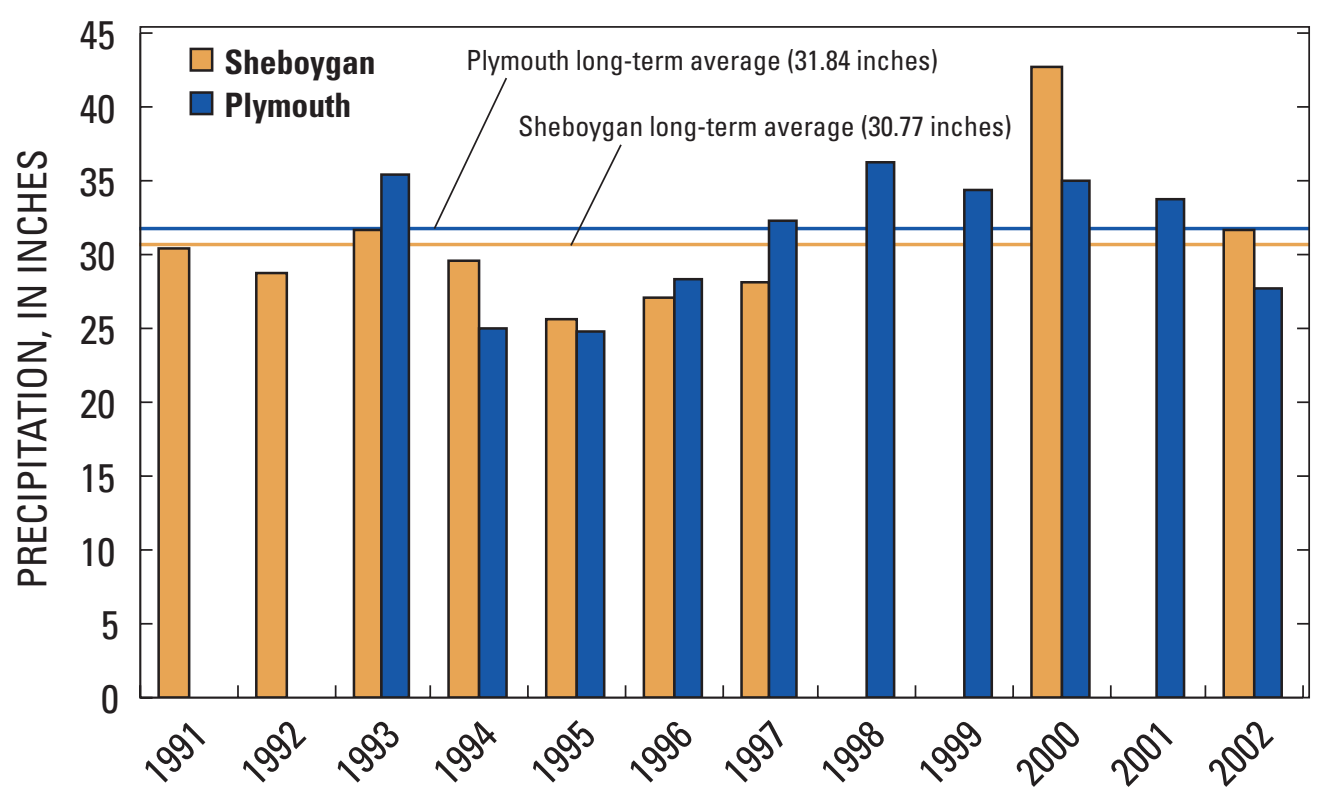

Figure 5. Yearly precipitation throughout the study period and long-term average yearly precipitation at Plymouth and Sheboygan, Wis.

year in "Water Resources Data, Wisconsin" for water years 1991 through 2002 (Holmstrom and others, 1992-2000,

Garn and others, 2001, and Waschbusch and others, 20022003). These data were used to determine streamflow characteristics and to compute nutrient and total suspended solids loads. In addition, daily mean base-flow contributions were separated from the daily mean streamflows (White and Sloto, 1990), and overland runoff (stormflow) was determined by computing the difference between daily mean streamflow and daily mean base flow. The mean annual streamflow at Otter Creek during the study period was $6.45 \mathrm{ft}^{3} / \mathrm{s}$, of which 75 percent was base flow (figs. 7 and 9). The mean flow for the pre-BMP implementation period was $7.66 \mathrm{ft}^{3} / \mathrm{s}$ (76 percent base flow) and for the post-BMP implementation period was $6.69 \mathrm{ft}^{3} / \mathrm{s}(75$ percent base flow). The greatest mean overall streamflow and base flow occurred in 1993.

Seasonal and Hydrologic Distribution of Loads: Daily mass loads were computed for total suspended solids, total phosphorus, and dissolved ammonia nitrogen for

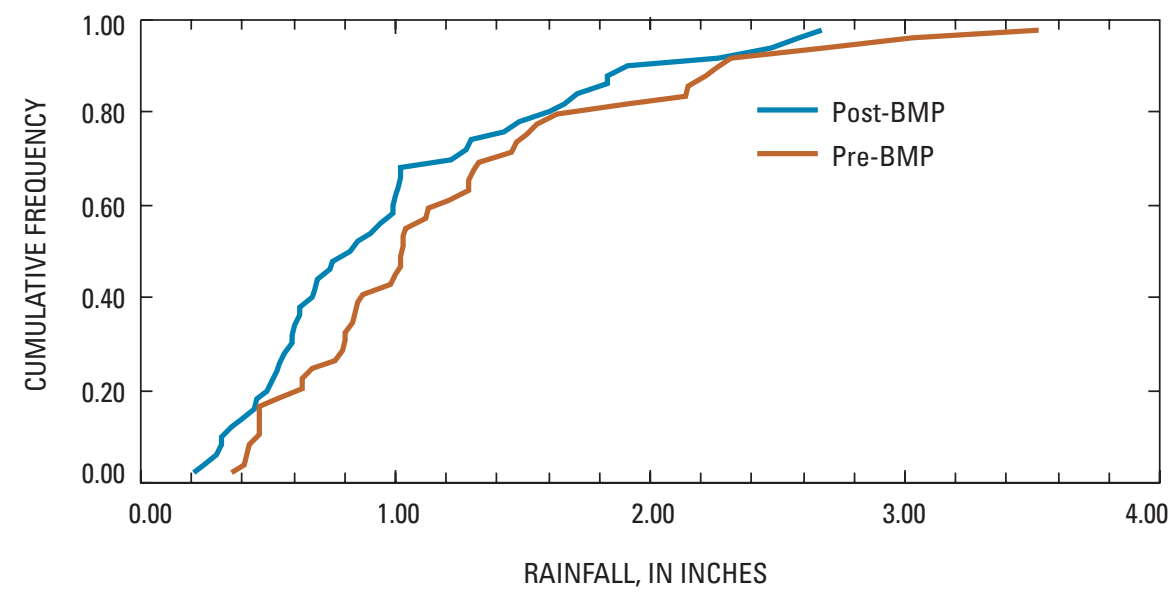

Figure 6. Cumulative rainfall distributions for the pre- and post-BMP (best-management practices) implementation period at Otter Creek, Sheboygan County, Wis. 

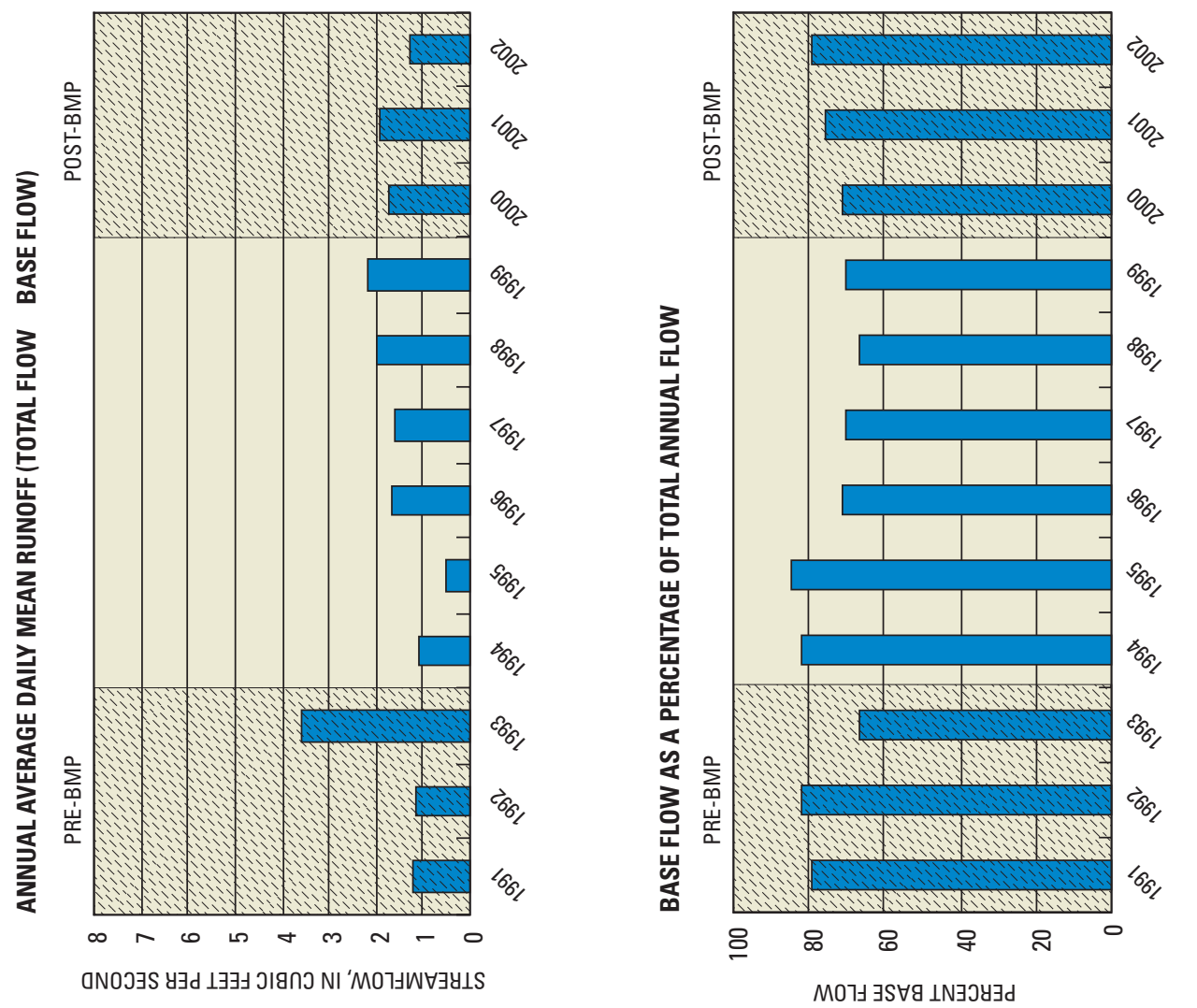

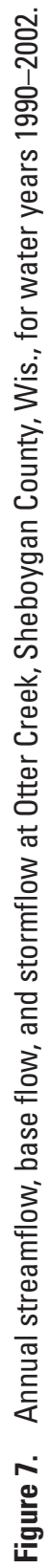




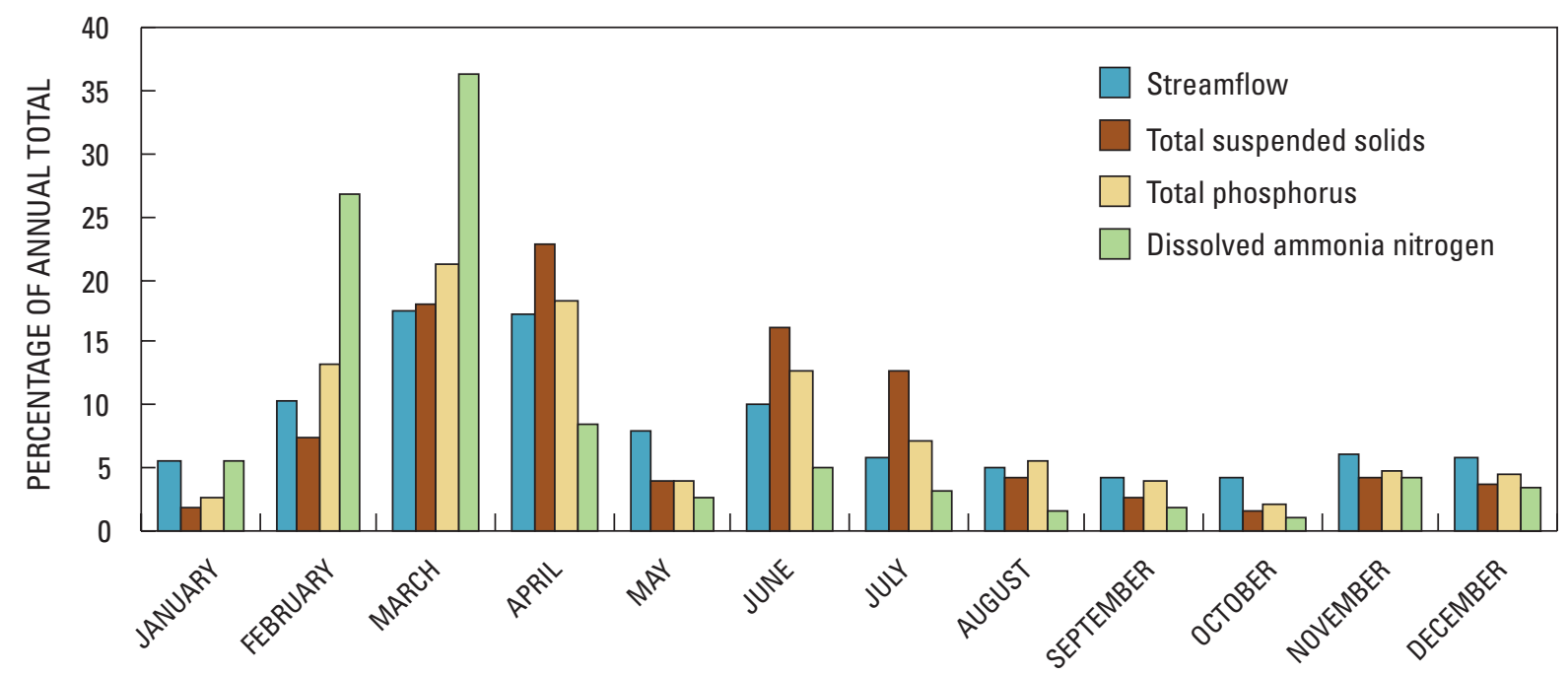

Figure 8. Average monthly distribution of streamflow and total suspended solids, total phosphorus, and dissolved ammonia nitrogen loads at Otter Creek, Sheboygan County, Wis., for water years 1990-2002.

the entire monitoring period. These values were used to compute mean monthly loads in order to understand how the loads were distributed throughout the year (fig. 8). The months during late winter and early spring contribute the greatest constituent loads at Otter Creek. The greatest total suspended solids loads were delivered in March and April with 41 percent of the mean annual load occurring in those 2 months. An additional 29 percent of the mean annual total suspended solids load occurred during June and July, whereas the remaining eight months all contributed less than 8 percent per month. The three largest monthly contributions occurred during February, March, and April for both total phosphorus and dissolved ammonia (a total of 53 and 71 percent of the average annual load, respectively).

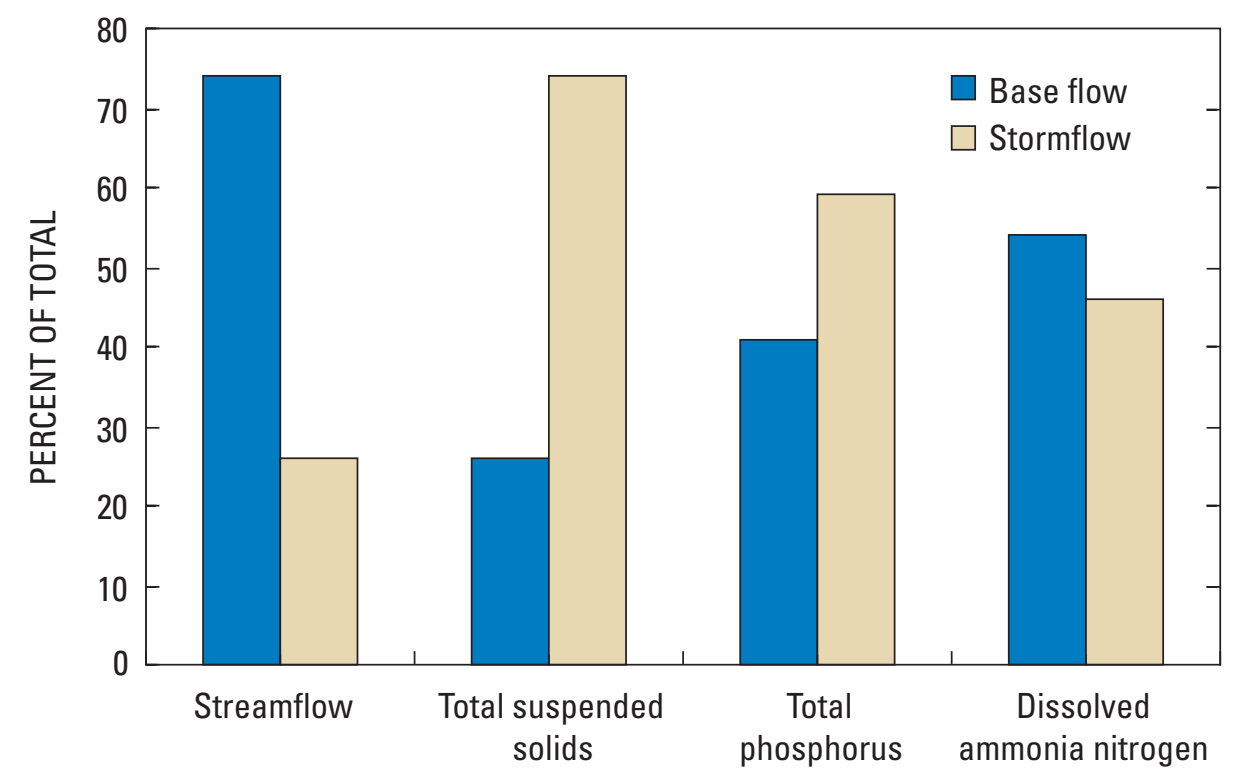

CONSTITUENT

Figure 9. Average relative annual contributions of stormflow and base-flow periods to streamflow, total suspended solids, total phosphorus, and dissolved ammonia nitrogen loadings at Otter Creek, Sheboygan County, Wis., for water years 1990-2002. 
Additionally, streamflow and loads were separated into annual base-flow and stormflow contributions (fig. 9). Greater than 70 percent of streamflow contributions were during base-flow periods whereas the opposite was true for contributions of total suspended solids. Approximately 59 percent of the mean annual total phosphorus load was contributed during stormflow periods. Dissolved ammonia load contributions were nearly equal during storm periods and base-flow periods.

Average monthly base-flow and stormflow contributions as a percentage of the annual total streamflow and constituent loads were computed to provide further insight into the mechanisms driving these parameters (fig. 10).

- Streamflow. Average monthly base-flow contributions were greater than stormflow contributions for all months, with the peaks of both base-flow and stormflow volumes in March and April.

- Total suspended solids. Average monthly contributions of total suspended solids loads were greater during storm periods than base-flow loads in all months except January, with the greatest contributions occurring during March, April, June, and July.

- Total phosphorus. Average monthly loads were substantially greater in stormflow than in base flow for five months. Stormflow and base-flow loads were within 20 percent of each other during 6 months, whereas January was the only month that average base-flow loads exceeded stormflow loads by more than 20 percent.

\section{- Dissolved ammonia nitrogen. Average monthly} loads were dominated by the months of February and March, with base-flow contributions of 34 percent and stormflow contributions of 29 percent of the mean annual load during those two months. Base-flow and stormflow contributions throughout the year were similar in magnitude on a month-bymonth basis.

The distribution of average monthly loads and average annual loads suggests that different constituents exhibit different behaviors depending on their particulate and dissolved fractions. Total suspended solids consists of 100 percent particulate matter, total phosphorus comprises both particulate and dissolved fractions, and dissolved ammonia nitrogen is completely in solution. Total suspended solids loads are dominated by stormflow; total phosphorus loads are greater in stormflow, but total phosphorus loads during base flow are more influential than those for total suspended solids; and dissolved ammonia nitrogen loads are equally influenced by stormflow and base flow. These data suggest that the constituents containing particulate fractions are most influential during stormflow and constituents containing dissolved fractions have increased influence during base flow. With this information and the monthly load data, it is apparent that the transport mechanisms and sources of these three constituents vary to some degree. Two primary pathways from sources to the stream are through surface runoff and ground-water discharge. The pathway of total suspended solids would be limited mainly to surface runoff, whereas the dissolved fractions of total phosphorus and ammonia nitrogen can also be transported through the shallow ground-water system and discharged to the stream in base flow. Solids will tend to settle out more during base-flow periods since stream velocities are lower during these periods than during storms. Also, the outlet to Big Gerber Lake will contain some phosphorus and dissolved ammonia nitrogen during base flow but most likely will have very little suspended solids. Average monthly concentrations of dissolved ammonia nitrogen in base flow and stormflow, as calculated by the monthly load divided by the monthly water volumes, are notably greater during January through March as compared to other months; in contrast, average monthly concentrations of phosphorus were similar throughout the year. Average monthly total suspended solids concentrations were lower during January and February than in other months and greatest during runoff periods in July.

Higher concentrations and loads of dissolved ammonia nitrogen in winter could have several possible explanations, all based on the assumption that stream $\mathrm{pH}$ levels keep most dissolved ammonia nitrogen in the form of ammonium. First, winter spreading of manure on crop lands may result in greater concentrations and loads because infiltration would be reduced on frozen ground, microbial organisms needed for oxidation of ammonium would not be as active in cold winter temperatures, and contact with soils that have the potential to remove ammonium from the manure-influenced runoff would be reduced. Second, water from the outlet of Big Gerber Lake may have increased dissolved ammonia nitrogen if anoxic conditions exist in the lake during periods of ice cover. Data are not available to confirm this.

The implications of this information on identifying sources of individual constituents are as follows: Total suspended solids contributions would be greatest from areas of active surface runoff; land uses that promote infiltration would decrease total suspended solids loads. Total phosphorus and dissolved ammonia nitrogen would 

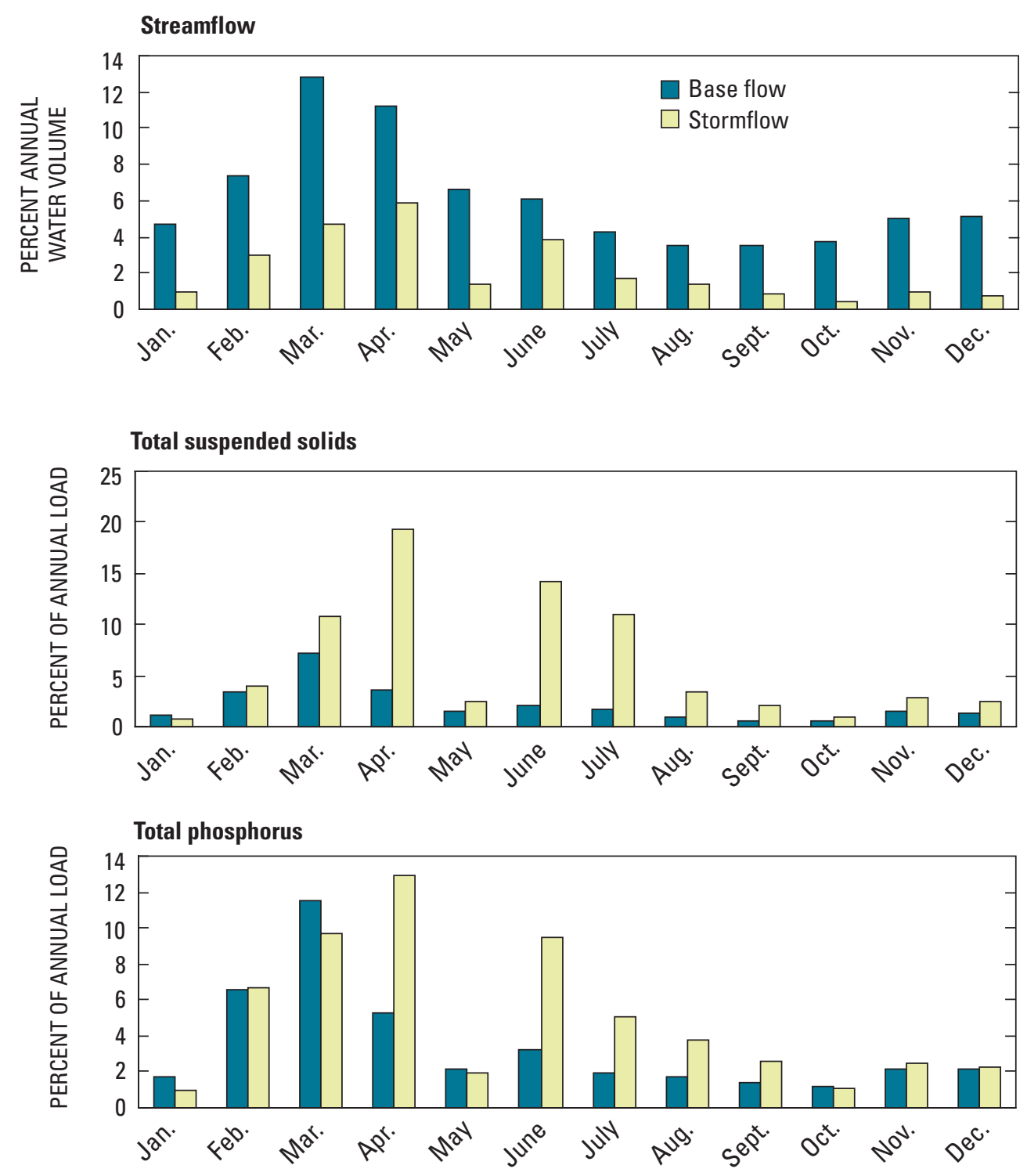

Dissolved ammonia nitrogen

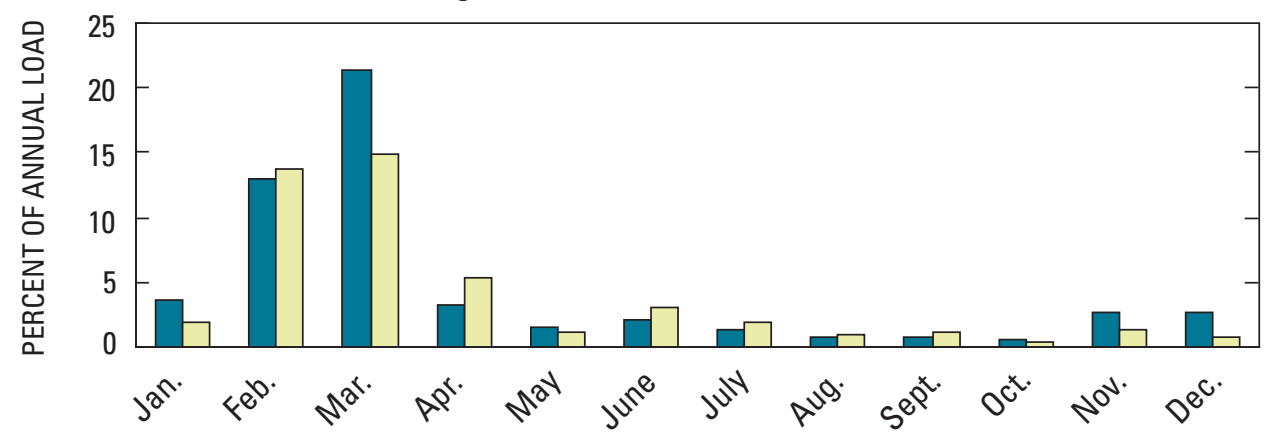

Figure 10. Average monthly streamflow and loads of total suspended solids, total phosphorus, and dissolved ammonia nitrogen during base flow and stormflow periods, expressed as a percentage of the annual total water volume and constituent loads at Otter Creek, Sheboygan County, Wis. 
be greatest from areas of active surface runoff, but the dissolved fraction could also enter the stream through infiltration and subsequent ground-water transport to the stream; land uses that promote infiltration would reduce the phosphorus and dissolved ammonia nitrogen load during surface-runoff periods but may or may not change the total phosphorus and dissolved ammonia nitrogen load during base-flow periods. The Gerber lake system has potential to influence water quality, but more data would be necessary to quantify these influences.

\section{Water Quality Before and After Implementation of Best- Management Practices}

The primary objective of this study was to evaluate overall BMP effectiveness at the watershed scale. BMPs implemented in the Otter Creek Watershed over the course of the study can potentially affect the stream in numerous different ways. Changes in water chemistry were evaluated using results from base-flow sampling and also by evaluating storm loads from rainfall periods. Numerous variables resulting from habitat and fish sampling were explored to evaluate changes in biology and factors directly affecting biology of the stream. Land-use data were used to interpret results from these analyses and to help understand the effects of individual BMP types.

\section{Constituent Concentrations at Base Flow}

Base flow in Otter Creek consists of ground-water contributions and discharge from lake outlets in the watershed. Water-quality sample results from base-flow concentrations, therefore, will reflect a combination of lake and ground-water discharges and direct surface influence in the stream. Consequently, base-flow water quality may be affected by some land-use practices in the watershed that affect direct surface influences (such as streambank protection) and others that affect infiltration to ground water (such as filter strips). Big and Little Gerber Lakes will capture flows from upstream and slowly release those flows to Otter Creek at the outlet to the lakes. In this process, some particulate matter will settle out, reducing loads of total suspended solids and possibly nutrients at the outlet. For this reason, the watershed area upstream from the lakes will have less immediate effect on the stream conditions downstream from the lakes during periods of increased runoff, but the lakes would have a long-term effect during base flow.
Fixed-interval water-quality samples were collected throughout the pre- and post-BMP periods. Base-flow samples were separated from the fixed interval samples for use in subsequent data analysis. Base-flow samples were identified by use of a combination of techniques. First, daily mean streamflow was separated into base-flow and overland-runoff components. For any given fixed-interval sample, if the ratio of instantaneous discharge to daily mean base flow was less than or equal to 0.95 , that sample was considered to be a potential base-flow sample. In addition, an estimation of the time lag for overland runoff in the watershed was computed as the drainage area in square miles raised to the exponent 0.2 (Viessman and others, 1977). The overland-runoff time lag was determined to be 2 days for Otter Creek, so potential base-flow samples that were collected within 2 days of the peak of a hydrograph were not considered to be base-flow samples.

A total of 184 samples were collected during base flow for total suspended solids, 184 for total phosphorus, 183 for dissolved ammonia nitrogen, 175 for $\mathrm{BOD}_{5}$, and 151 for fecal coliform during the study (fig. 11).

Statistical analyses (Wilcoxon rank-sum test) were used to test for significant differences between base-flow results from samples collected during the pre- and postBMP periods (Helsel and Hirsch, 1992). These analyses were done on three different temporal arrangements of the base-flow data: first with all pre- and post-BMP data, second with data from November through May (the nonvegetative season), and third with data from June through October (the vegetative season). Data from samples collected during the nonvegetative season were differentiated from data collected during the vegetative season to explore the possibility of seasonal differences in BMP effectiveness.

Results of the Wilcoxon rank-sum nonparametric test indicate significant differences at the 95-percent confidence level between pre- and post-BMP base-flow concentrations for some constituents but not for others (table 2). Results from the data set with all base-flow samples included indicate a decrease in total suspended solids and $\mathrm{BOD}_{5}$ concentrations, an increase in fecal coliform concentrations, and no detectable change in dissolved ammonia nitrogen and phosphorus concentrations. For samples collected during the nonvegetative season, results indicate a decrease in $\mathrm{BOD}_{5}$ concentrations and no changes in the other four constituents. For samples collected during the vegetative season, a decrease is again noted in the $\mathrm{BOD}_{5}$ concentrations, significant increases are shown for total phosphorus and fecal coliform, and no changes are detectable for dissolved ammonia nitrogen and 

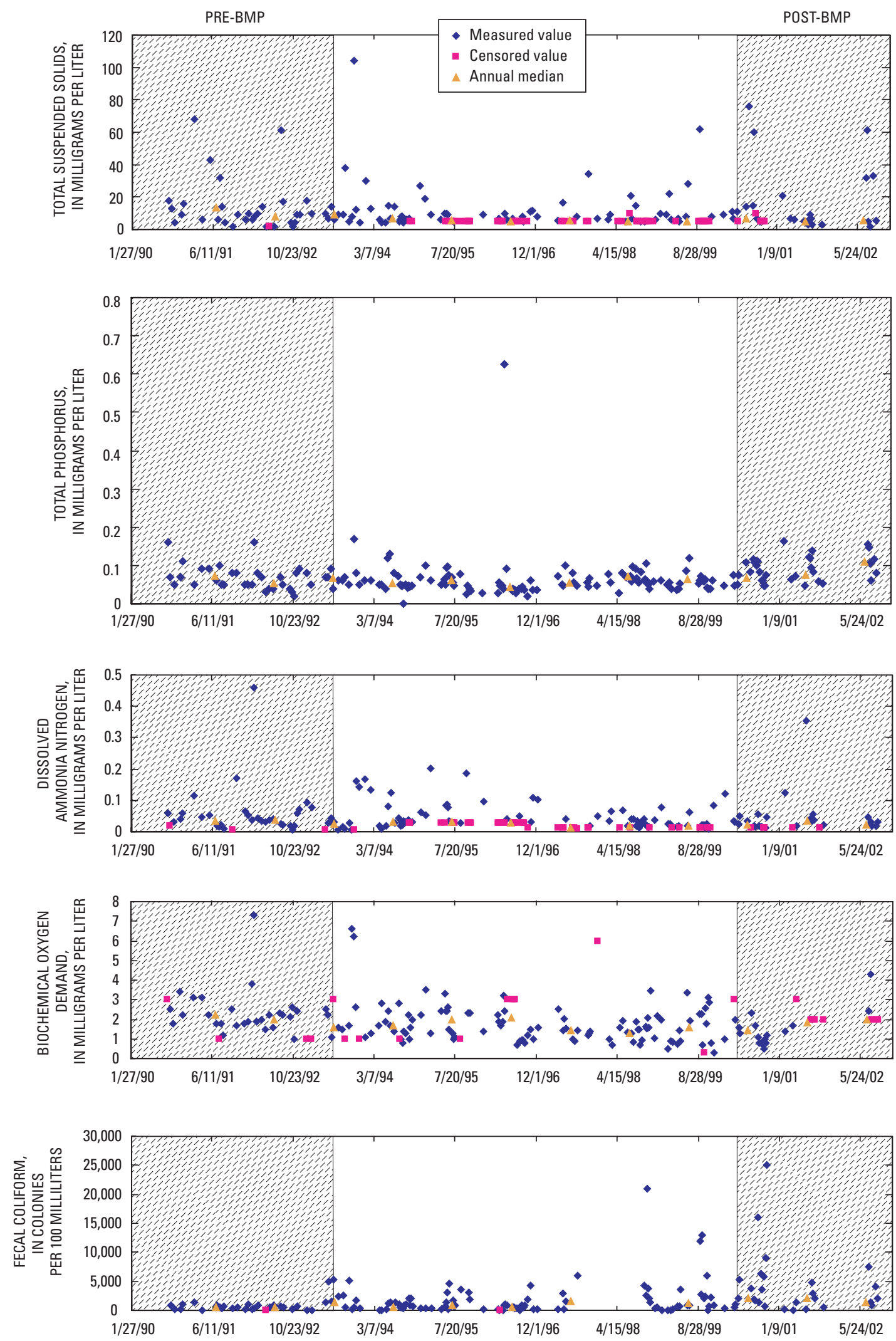

Figure 11. Concentrations and water-year medians of total suspended solids, total phosphorus, dissolved ammonia nitrogen, biochemical oxygen demand, and fecal coliform in base-flow samples throughout the study period at Otter Creek, Sheboygan County, Wis. 
Table 2. Results of Wilcoxon rank-sum test for differences between constituent concentrations in base-flow samples from preand post-BMP implementation periods at Otter Creek, Sheboygan County, Wis.

$[\mathrm{mg} / \mathrm{L}$, milligrams per liter; BMP, best-management practice; bold text indicates a statistically significant change in concentration between pre- and postBMP implementation periods]

\begin{tabular}{|c|c|c|c|c|}
\hline \multirow[b]{2}{*}{ Response variable } & \multirow{2}{*}{$\begin{array}{l}\text { Number of } \\
\text { samples for } \\
\text { pre-/post- } \\
\text { BMP periods }\end{array}$} & \multicolumn{3}{|c|}{$\begin{array}{l}\text { Median concentration } \\
\text { (mg/L) }\end{array}$} \\
\hline & & Pre-BMP & Post-BMP & Significance level \\
\hline \multicolumn{5}{|c|}{ Combined seasons } \\
\hline Total suspended solids & $40 / 40$ & 9.0 & 5.2 & 0.02/decrease \\
\hline Total phosphorus & $40 / 41$ & 0.07 & 0.074 & 0.052 \\
\hline Dissolved ammonia nitrogen & $40 / 41$ & 0.0325 & 0.022 & 0.06 \\
\hline Biochemical oxygen demand & $39 / 37$ & 2.0 & 1.1 & $0.0001 /$ decrease \\
\hline Fecal coliform & $34 / 37$ & 550 & 2,000 & 0.0002/increase \\
\hline \multicolumn{5}{|c|}{ Nonvegetative season } \\
\hline Total suspended solids & $21 / 11$ & 9.0 & 7.0 & 0.11 \\
\hline Total phosphorus & $21 / 11$ & 0.07 & 0.061 & 0.088 \\
\hline Dissolved ammonia nitrogen & $21 / 11$ & 0.053 & 0.03 & 0.066 \\
\hline Biochemical oxygen demand & $20 / 11$ & 2.2 & 1.3 & $0.001 /$ decrease \\
\hline Fecal coliform & $18 / 11$ & 490 & 810 & 0.13 \\
\hline \multicolumn{5}{|c|}{ Vegetative season } \\
\hline Total suspended solids & $19 / 29$ & 9.0 & 5.0 & 0.29 \\
\hline Total phosphorus & $19 / 30$ & 0.06 & 0.082 & $0.004 /$ increase \\
\hline Dissolved ammonia nitrogen & $19 / 30$ & 0.018 & 0.021 & 0.36 \\
\hline Biochemical oxygen demand & $19 / 26$ & 1.8 & 1.1 & $0.029 /$ decrease \\
\hline Fecal coliform & $16 / 26$ & 675 & 2,250 & 0.0013/increase \\
\hline
\end{tabular}

total suspended solids. There is agreement from analysis of all three data sets that the concentration of $\mathrm{BOD}_{5}$ has decreased in base flow from the pre- to post-BMP periods with a reduction in median concentrations of 45 percent. The medians of total suspended solids concentrations are also reduced from the pre- to post-BMP periods, but this difference is statistically significant only in the overall data set and not in the vegetative or the nonvegetative seasonal data sets. This result could be due to the reduced sample size and the large variability of total suspended solids data in the seasonal data sets, as compared to only 22- and 34-percent reductions in median concentrations. The medians of base-flow concentrations for dissolved ammonia nitrogen are reduced from the pre- to the postBMP periods in the overall data set and the data collected during the nonvegetative season, but they remain nearly the same for samples collected during the vegetative season. None of these results prove to be statistically significant at the 95-percent confidence level even though the overall median dissolved ammonia nitrogen concentration shows a 32-percent reduction from the pre- to the post-BMP periods. The increase in median fecal coliform concentrations is significant for the overall data set and for samples collected during the vegetative season. This result is notable, with an increase of 260 percent from the pre- to the post-BMP periods. The cause of this sharp increase has not been determined. Overall total phosphorus concentrations in base flow do not seem to change significantly except for a 37 -percent increase during the vegetative season.

\section{Storm Loads}

Because much of the annual total suspended-solids and nutrient transport occurs during storms, fixed-interval sampling — particularly at a monthly frequency_may not show changes resulting from BMP implementation (Walker, 1993). Consequently, mass transport resulting from individual rainfall storms was analyzed. Stream water was sampled numerous times per storm for each storm used in the analysis (average of 8 samples per storm, minimum of 2 samples per storm, and maximum of 29 samples per storm). Instantaneous mass transport of a particular constituent was determined by multiplying streamflow by the concentration of the constituent and a conversion factor 
(Porterfield, 1972). The integration method was then used to determine the mass transport of each constituent for each storm (Porterfield, 1972), expressed as a storm load. Concentration at the beginning of a storm was estimated from samples collected during previous base-flow periods between storms. Concentration at the end of the storm was estimated from samples collected immediately after the end of the storm. Some concentration data for individual storms were estimated by the relation between concentration and streamflow. These estimates were kept to a minimum.

In many cases, the variability in the storm loads is large enough to mask potential differences in the pre- and post-BMP periods. In addition, because the pre- and postBMP periods arise from different hydrologic conditions, differences in the hydrologic conditions could result in differences that are not a result of the management practices. For these reasons, one solution is to perform regressions relating the storm loads to variables representing climatic and seasonal conditions. If the explanatory variables remove variability representing the natural climatologic and seasonal conditions, then the variability remaining in the regression residuals represents the combination of changes induced by the BMPs and model error. Because the regression, by design, reduces the variability in the data, it should theoretically be possible to detect smaller differences between the pre- and post-BMP periods than to detect differences in the storm loads.

Several explanatory variables were selected for use in the regressions, most of which were based on various measures of precipitation for each distinct rainfall storm. These included total rainfall $(\mathrm{P})$, the 15- and 30-minute maximum intensities $\left(\mathrm{I}_{15}\right.$ and $\mathrm{I}_{30}$ ), and the Universal Soil Loss Equation (USLE) erosivity index (EI) (Wischmeier and Smith, 1978). Additional precipitation-based measures included the 1-, 3-, and 5-day antecedent precipitation $\left(\mathrm{API}_{1}, \mathrm{API}_{3}\right.$, and $\left.\mathrm{API}_{5}\right)$, which is computed as the total rainfall for the 1,3, and 5 days prior to the beginning of each storm, respectively. Terms combining total rainfall and the antecedent precipitation also were considered (for example, $\mathrm{P}+\mathrm{API} \mathrm{I}_{1}$ ). Finally, two seasonal terms were included to allow for variations arising solely on the basis of the time of year. The seasonal terms were based on the serial date of the storm (T), using a period of 1 year and both sine and cosine terms to allow for amplitude and phase-shift estimation.

Because hydrologic conditions and, hence, constituent loads can be quite different because of crop cover, a further seasonal distinction was used. The period from June 1-October 31 represents the time when more vegeta- tion is present than the remainder of the year. Separate analyses were done for these two seasons.

Preliminary regression results indicated that, for many of the constituents and storms, simple linear regressions resulted in the prediction of negative storm loads. Because this would result in erroneous conclusions when comparing pre- and post-BMP periods, the final regressions were based on a logarithmic transformation of the storm loads, thus assuring that negative loads cannot be predicted.

For each constituent, stepwise regressions were done on the explanatory variables described above (table 3 ). For each regression, additional variables were considered if the improvement in the resulting regression was considered large enough to warrant their use (a coefficient significantly different from zero at the 95-percent confidence level). In addition, various regression plots were examined to verify that the underlying assumptions of regression analysis were not violated.

The regression residuals also were tested for differences between the pre- and post-BMP periods (table 4). The median storm loads from rainfall periods for all three constituents for the pre-BMP and post-BMP periods are also listed in table 4. Regression residuals for the two periods were compared statistically by means of the Wilcoxon rank-sum test, as described previously. If the regressions represent variability due to natural factors, a difference in the regression residuals could be attributed directly to a difference due to the BMPs.

For combined seasons, all median storm loads from rainfall periods decreased. Testing the storm-load residuals demonstrates that this decrease is statistically significant for both total suspended solids and dissolved ammonia nitrogen at the 95-percent confidence level (table 4), but not for total phosphorus. Therefore, for total suspended solids and dissolved ammonia nitrogen, the difference in pre- and post- BMP conditions is likely due to the BMPs installed.

For the nonvegetative season, again all median storm loads from rainfall periods decreased. The storm-load residuals demonstrate that this difference is statistically significant for all three constituents (table 4). For the vegetative season, all median storm loads from rainfall periods decreased, but none of these differences were statistically significant at the 95-percent confidence level based on storm-load residuals. Differences in median storm loads from rainfall periods for the pre- and post-BMP conditions in the nonvegetative season are likely due to installation of BMPs; however, in the case of the vegetative season, the decrease in median storm loads from rainfall periods was not verified with these statistical tests, so it may have 
Table 3. Regression results for storm loads from rainfall periods at Otter Creek, Wis., for combined and separate seasons.

$\left[I_{n}, n\right.$-minute maximum precipitation intensity; P, total precipitation; API, $n$-day antecedent precipitation; T, serial date of storm; $R^{2}$, fraction of the variance of response variables explained by the explanatory variables for the model]

\begin{tabular}{|c|c|c|c|c|c|}
\hline Response variable & Explanatory variables & Sample size & Adjusted R ${ }^{2}$ & $\begin{array}{c}\text { Standard } \\
\text { error }\end{array}$ & $\begin{array}{l}\text { Standard errot } \\
\text { (percent) }\end{array}$ \\
\hline \multicolumn{6}{|c|}{ Combined seasons } \\
\hline Total suspended solids & $\mathrm{I}_{30}, \mathrm{P}+\mathrm{API}_{1}, \mathrm{P}+\mathrm{API}_{5}, \cos (\mathrm{T})$ & 61 & 0.573 & 1.19 & 149 \\
\hline Total phosphorus & $\mathrm{I}_{15}, \mathrm{P}+\mathrm{API}_{1}, \mathrm{P}+\mathrm{API}_{5}, \sin (\mathrm{T})$ & 61 & .536 & .832 & 93.1 \\
\hline Dissolved ammonia nitrogen & $\mathrm{P}+\mathrm{API}_{1}, \mathrm{P}+\mathrm{API}_{5}, \sin (\mathrm{T}), \cos (\mathrm{T})$ & 60 & .546 & .691 & 74.7 \\
\hline \multicolumn{6}{|c|}{ Nonvegetative season } \\
\hline Total suspended solids & $\mathrm{P}+\mathrm{API}_{1}, \cos (\mathrm{T})$ & 31 & 0.436 & 1.32 & 174 \\
\hline Total phosphorus & $\mathrm{P}+\mathrm{API}_{5}, \sin (\mathrm{T}), \cos (\mathrm{T})$ & 31 & .520 & .705 & 76.5 \\
\hline Dissolved ammonia nitrogen & $\mathrm{P}+\mathrm{API}_{5}, \sin (\mathrm{T}), \cos (\mathrm{T})$ & 31 & .514 & .680 & 73.4 \\
\hline \multicolumn{6}{|c|}{ Vegetative season } \\
\hline Total suspended solids & $\mathrm{P}+\mathrm{API}_{5}, \sin (\mathrm{T})$ & 30 & 0.652 & 1.12 & 137 \\
\hline Total phosphorus & $\mathrm{P}+\mathrm{API}_{5}, \sin (\mathrm{T})$ & 30 & .529 & .973 & 113 \\
\hline Dissolved ammonia nitrogen & $\mathrm{P}+\mathrm{API}_{5}, \sin (\mathrm{T})$ & 29 & .423 & .732 & 79.9 \\
\hline
\end{tabular}

Table 4. Median rainfall-period storm loads and results of the Wilcoxon rank-sum test comparing storm-load residuals for preand post-BMP periods at Otter Creek, Wis.

[Total suspended-solids loads are in tons; BMP, best-management practice; bold text indicates a statistically significant change in concentration between pre- and post-BMP implementation periods; lbs, pounds]

\begin{tabular}{|c|c|c|c|}
\hline \multirow[b]{2}{*}{ Variable } & \multicolumn{2}{|c|}{ Median storm loads } & \multirow{2}{*}{$\begin{array}{c}\text { Storm-load residuals } \\
\text { Significance level }\end{array}$} \\
\hline & Pre-BMP & Post-BMP & \\
\hline & \multicolumn{2}{|c|}{ Combined seasons } & \\
\hline Total suspended solids (tons) & 8.3 & 3.0 & 0.031 \\
\hline Total phosphorus (lbs) & 69.4 & 30.3 & 0.186 \\
\hline \multirow[t]{2}{*}{ Dissolved ammonia nitrogen (lbs) } & 32.6 & 13.4 & 0.037 \\
\hline & \multicolumn{2}{|c|}{ Nonvegetative season } & \\
\hline Total suspended solids (tons) & 11.9 & 4.1 & 0.0047 \\
\hline Total phosphorus (lbs) & 75.7 & 54.4 & 0.038 \\
\hline \multirow[t]{2}{*}{ Dissolved ammonia nitrogen (lbs) } & 34.8 & 20.1 & 0.028 \\
\hline & \multicolumn{2}{|c|}{ Vegetative season } & \\
\hline Total suspended solids (tons) & 8.3 & 2.2 & 0.802 \\
\hline Total phosphorus (lbs) & 57.0 & 25.4 & 0.770 \\
\hline Dissolved ammonia nitrogen (lbs) & 18.5 & 8.5 & 0.319 \\
\hline
\end{tabular}


been due to something other than BMP implementation. One possibility is that hydrologic conditions were different between rainfall storms monitored during the vegetative seasons of the pre- and post-BMP periods.

The difference between pre- and post-BMP median storm loads from rainfall periods does not really reflect the percentage reduction in the individual rainfall storm loads largely because the pre- and post-BMP periods monitored different hydrologic conditions. Use of separate pre- and post-BMP regressions allows prediction of the theoretical pre- and post-BMP storm loads from rainfall periods for different values of the explanatory variables. For these conditions, the difference in the loads predicted by the preand post-BMP regressions represents the theoretical reduction in load. All explanatory variables with a coefficient significantly different from zero at the 95-percent confidence level were included in the regressions; all regressions were significant at the 95-percent confidence level. The regressions computed for the pre-BMP conditions were then used to predict what the theoretical pre-BMP load would have been for the explanatory variables for all of the monitored rainfall storms. Likewise, the regressions computed for the post-BMP conditions were used to predict the theoretical post-BMP storm loads for all the monitored rainfall storms. The percentage reduction was then computed based on the theoretical pre- and post-BMP loads, and averaged across all of the monitored rainfall storms. In a few cases, the theoretical post-BMP load exceeded the theoretical pre-BMP load. This is not surprising, as separate regressions were computed for the pre- and post-BMP conditions, and for most of the regressions the explanatory variables differed slightly. This occurred for less than 10 percent of the storms, and the resulting negative percent reductions were included in the calculation of the average percent reduction for each constituent. The resulting average percent reductions of monitored rainfall storms for the entire study period for separate and combined seasons are given in table 5 .

\section{Biological Data Before and After Installation of Best-Management Practices}

Variations in stream channel morphology, substrate composition, and overall fish-habitat condition for Otter Creek and the reference streams were considerable. During the early sampling years (1990-93), the variation was greater than during the rest of the study years. For example, embeddedness varied 76 percent in the first three years as compared to 25 percent in the remaining years for station 1 at Otter Creek, 78 percent as compared to 21 percent for station 1 at Pigeon River, and 32 percent as compared to 26 percent for station 1 at Meeme River. Cobble and gravel substrates varied 34 percent in the first three years and 26 percent during the remaining years for Otter Creek, 51 percent as compared to 29 percent for Pigeon River, and 29 percent as compared to 21 percent for Meeme River. Pigeon River stations and Otter Creek station 4 varied more than the other stations. These stations had narrower and deeper channels than other sampled stations.

ANCOVA indicated that the overall stream-habitat quality in Otter Creek was improved by BMP implementation for stream segments that had either natural riparian buffer or stream segments where streambank fencing was installed (table 6). For stations 1, 2, and 3, eight of the ten monitored habitat variables were significantly improved (at the 95-percent confidence level) by BMP implementation. Substrate embeddedness, bank erosion, sediment depth, silt and sand substrates, and width-depth ratio were negatively correlated with BMP implementation. Conductivity, gravel and rubble substrates, and overall habitat

Table 5. Average percent reductions predicted across all monitored storms by use of pre- and post-BMP regressions to estimate loads from rainfall periods at Otter Creek, Wis.

[BMP, best-management practice]

\begin{tabular}{lccc}
\hline \multicolumn{1}{c}{ Variable } & \multicolumn{3}{c}{ Season } \\
\cline { 2 - 4 } & $\begin{array}{c}\text { Nonvegetative } \\
\text { (percent) }\end{array}$ & $\begin{array}{c}\text { Vegetative } \\
\text { (percent) }\end{array}$ & $\begin{array}{c}\text { Combined } \\
\text { (percent) }\end{array}$ \\
\hline Total suspended solids & 73 & 41 & 58 \\
Total phosphorus & 61 & 34 & 48 \\
Dissolved ammonia nitrogen & 42 & 40 & 41 \\
\hline
\end{tabular}


Table 6. Results of trend analysis comparing habitat for pre- and post-BMP periods using analysis of covariance ${ }^{1}$ with the treatment station and reference stations, Otter Creek, Meeme River, and Pigeon River, Wis.

[BMP, best-management practice; $\mathrm{P}$, significance level; $\mathrm{R}^{2}$, fraction of the variance of response variables explained by the explanatory variables for the model; $\mu \mathrm{s} / \mathrm{cm}$, microsiemens per centimeter; $\%$, percent; $\mathrm{m}$, meters; $e$, error; $\mathrm{Y}$, variable value of treatment site; $\mathrm{X}_{1}$, variable value of paired reference sites; $\mathrm{X}_{2}$, years since BMP implementation; $\beta_{\mathrm{o}}$ constant; $\beta_{1}$ change in $\mathrm{Y}$ per unit change in $\mathrm{X}_{1}$ when holding $\mathrm{X}_{2}$ constant; $\beta_{2}$, change in $\mathrm{Y}$ per unit change in $X_{2}$ when holding $X_{1}$ constant; bold values indicate a significant change in habitat variables $(p<0.05)$ ]

\begin{tabular}{|c|c|c|c|c|c|c|c|}
\hline Habitat variables & $\beta_{0}$ & $\beta_{1}$ & $\beta_{2}$ & $\mathbf{P}_{\beta 1}$ & $\mathbf{P}_{\beta 2}$ & $\mathbf{R}_{\text {model }}^{2}$ & $\mathbf{P}_{\text {model }}$ \\
\hline \multicolumn{8}{|l|}{ Test sites 1 to 3} \\
\hline $\begin{array}{l}\text { Specific conductance } \\
\quad(\mu \mathrm{s} / \mathrm{cm})\end{array}$ & 561 & -0.03 & 17.8 & 0.871 & 0.008 & 0.90 & 0.009 \\
\hline Embeddedness (\%) & 6.33 & 1.01 & -2.86 & 0.332 & 0.017 & 0.89 & 0.012 \\
\hline Bank erosion (\%) & 16.98 & -0.03 & -1.51 & 0.968 & 0.049 & 0.48 & 0.074 \\
\hline Rubble and gravel (\%) & 31.66 & 0.26 & 6.05 & 0.554 & 0.017 & 0.85 & 0.019 \\
\hline Riffle (\%) & -0.97 & 0.76 & 1.32 & 0.224 & 0.103 & 0.67 & 0.114 \\
\hline Cover for fish $(\%)$ & -1.72 & 0.25 & 0.07 & 0.015 & 0.831 & 0.84 & 0.026 \\
\hline Sediment depth (m) & 0.02 & 0.04 & -0.01 & 0.803 & 0.044 & 0.73 & 0.069 \\
\hline Silt and sand (\%) & 45.5 & 0.20 & -3.12 & 0.657 & 0.015 & 0.85 & 0.023 \\
\hline Width to depth ratio & 14.4 & 0.38 & -0.32 & 0.362 & 0.019 & 0.83 & 0.380 \\
\hline Habitat score & 6.80 & 0.65 & 1.11 & 0.035 & 0.028 & 0.85 & 0.022 \\
\hline
\end{tabular}

Test site 4

None of the above variable changes were significantly correlated to BMP implementation for site 4

${ }^{1}\left(\mathrm{Y}=\beta_{\mathrm{o}}+\beta_{1} * \mathrm{X}_{1}+\beta_{2} * \mathrm{X}_{2}+e\right)$

scores were positively correlated with BMP installation. The changes in percentages of riffle and cover for fish were not correlated with BMP implementation. In contrast, none of the habitat variable changes were correlated with BMP implementation at station 4 where riparian area was pasture and no streambank fencing was installed.

Fish abundance decreased in treatment- and reference-stream assessment sites during the 13 sampling years. Comparison of data from the first 3 years and the last 3 years showed that total fish abundance decreased 79 percent in Otter Creek and 65 percent in the reference streams. When all sampling years were considered, the percentages of tolerant fishes and omnivores increased in Otter Creek, whereas tolerant fishes decreased and insectivores increased in reference streams. Percentage of intolerant fishes and IBI score showed no obvious trend in Otter Creek or in reference streams.

When data from paired reference streams were incorporated as covariance to detect BMP influence on the treatment stream, ANCOVA indicated that fish abundance significantly decreased and percentage omnivore individuals increased in Otter Creek stations with natural or fenced riparian areas (table 7). Number of fish species and percentage of darter individuals significantly decreased in station 4 where the riparian area was pasture. None of the changes for the other evaluated variables was attributed to BMP implementation.

\section{Effects of Management Practices on Otter Creek}

Concentrations of nutrients and total solids observed during base flow and storms can be reduced by BMPs. For the purpose of discussion, BMPs can be divided into five main categories: animal-waste systems, fencing, streambank protection, nutrient-management, and upland-management practices. The Otter Creek Watershed is affected by a mixture of BMPs, and each BMP has varying success in controlling different aspects of the water quality, habitat, and biology of the stream. A description of individual BMPs and their potential effects on water quality has been previously published (Graczyk and others, 2003). Changes in fish communities would depend on a combination of changes in water quality and habitat. 
Table 7. Results of trend analysis comparing fish community data for pre-and post-BMP periods using analysis of covariance ${ }^{1}$ with the treatment station and reference stations, Otter Creek, Meeme River, and Pigeon River, Wis.

[BMP, best-management practice; $\mathrm{P}$, significance level; $\mathrm{R}^{2}$, fraction of the variance of response variables explained by the explanatory variables for the model; $\%$, percent; $\mathrm{ft}$, feet; $e$, error; No., number; $\mathrm{Y}$, variable value of treatment site; $\mathrm{X}_{1}$, variable value of paired reference sites; $\mathrm{X}_{2}$, years since $\mathrm{BMP}$ implementation; $\beta_{\mathrm{o}}$, constant; $\beta_{1 ;}$ change in $\mathrm{Y}$ per unit change in $\mathrm{X}_{1}$ when holding $\mathrm{X}_{2}$ constant; $\beta_{2}$, change in $\mathrm{Y}$ per unit change in $\mathrm{X}_{2}$ when holding $\mathrm{X}_{1}$ constant; bold values indicate a significant change in habitat variables $(\mathrm{p}<0.05)$ ]

\begin{tabular}{|c|c|c|c|c|c|c|c|}
\hline Fish variables & $\beta_{0}$ & $\beta_{1}$ & $\beta_{2}$ & $\mathbf{P}_{\beta 1}$ & $\mathbf{P}_{\beta 2}$ & $\mathbf{R}_{\text {model }}^{2}$ & $\mathbf{P}_{\text {model }}$ \\
\hline \multicolumn{8}{|l|}{ Test sites 1 to 3} \\
\hline Number of species & 7.08 & 0.61 & -0.71 & 0.157 & 0.098 & 0.49 & 0.192 \\
\hline Abundance (No./328 ft) & 964 & 0.07 & -68.5 & 0.684 & 0.017 & 0.73 & 0.019 \\
\hline Index of biotic integrity & 29.2 & 0.62 & -2.23 & 0.252 & 0.181 & 0.44 & 0.178 \\
\hline Darter individuals (\%) & 10.9 & 0.24 & -0.65 & 0.528 & 0.133 & 0.40 & 0.214 \\
\hline Intolerant individuals (\%) & 1.80 & -0.38 & -0.11 & 0.715 & 0.353 & 0.26 & 0.385 \\
\hline Omnivore individuals (\%) & 3.08 & 0.07 & 2.24 & 0.729 & 0.002 & 0.87 & 0.002 \\
\hline Insectivore individuals (\%) & 29.8 & 0.20 & -1.19 & 0.385 & 0.341 & 0.15 & 0.611 \\
\hline Lithophil individuals (\%) & 49.8 & 0.19 & -1.29 & 0.556 & 0.193 & 0.44 & 0.172 \\
\hline Tolerant individuals (\%) & 40.9 & 0.30 & 1.47 & 0.193 & 0.154 & 0.31 & 0.317 \\
\hline \multicolumn{8}{|l|}{ Test site 4} \\
\hline Number of species & 13.2 & 0.42 & -0.72 & 0.461 & 0.045 & 0.60 & 0.064 \\
\hline Darter individuals (\%) & 22.5 & -0.31 & -1.39 & 0.562 & 0.033 & 0.56 & 0.086 \\
\hline \multicolumn{8}{|c|}{ None of the other variable changes were significantly correlated to BMP implementation } \\
\hline
\end{tabular}

\section{Influence of BMPs on Water Quality}

Sampling results indicate an overall improvement in water quality as a result of BMP implementation in the Otter Creek Watershed. Base-flow concentrations were significantly reduced for total suspended solids and $\mathrm{BOD}_{5}$. These reductions were most likely caused by the installation of streambank fencing reducing the number of livestock in the stream, barnyard-runoff control systems, manure storage facilities, and milk house wastewater treatment systems. There was also a septic system connection to a drain tile that was disconnected in the summer of 1999. Median concentrations of dissolved ammonia nitrogen decreased, but neither total phosphorus nor dissolved ammonia nitrogen concentrations of samples collected during base-flow periods resulted in statistically significant differences from pre- to post-BMP periods. The reason for this result is uncertain considering the high level of nutrient management in the watershed, but this absence of change could be due to the already low concentrations of total phosphorus and dissolved ammonia nitrogen during base flow (table 2, fig. 11). Base-flow concentrations of total phosphorus and dissolved ammonia nitrogen during the pre-BMP period were below $0.2 \mathrm{mg} / \mathrm{L}$ except in one sample for dissolved ammonia nitrogen. Fecal coliform concentrations increased from the pre- to the post-BMP period. The cause of this result is uncertain.

Storm loads from rainfall periods in Otter Creek were significantly reduced for all three monitored waterquality constituents, as indicated by differences in stormload residuals (table 4). There are clear differences in the results between the nonvegetative and the vegetative seasons. Results from rainfall storms monitored during the nonvegetative season show significant reductions from the pre-BMP to the post-BMP period in storm loads of total suspended solids, total phosphorus, and dissolved ammonia nitrogen. Although median storm loads from rainfall periods are smaller in data from the vegetative season, none of these differences prove to be statistically significant.

Comparison of a combined data set from both the vegetative and the nonvegetative season shows significant reductions in total suspended solids and dissolved ammonia nitrogen storm loads from rainfall periods, as indicated by differences in storm-load residuals. The median total phosphorus storm load is reduced by 56 percent, yet this 
reduction is not statistically significant. This is most likely caused by a large scatter around the regression line, a lack of representative explanatory variables that adequately describe conditions needed to generate total phosphorus contributions to the stream, or a combination of these two factors.

Reductions in monitored constituents could have been due to a combination of factors. There were numerous BMPs installed during the study period, including animalwaste management systems, streambank protection, and upland-management practices. Since individual monitoring was not done for each BMP, it is not possible to quantitatively determine the effect of each type of BMP, but Sheboygan County Land and Water Conservation Department personnel assessed each of these BMPs and felt that the most effective BMPs for total suspended solids reduction were the buffer strips which provide an area for solids to settle before reaching the stream, and streambank fencing that allows for growth of vegetation on the streambank, reducing streambank erosion. For reductions in nutrients, it was felt that the most effective BMPs were streambank fencing which reduced the number of livestock in the stream, barnyard-runoff control systems, manure-storage facilities, and milk house wastewater treatment systems.

\section{Influence of BMPs on Habitat and Fish}

Habitat- and fish-sampling results imply that implementation of BMPs in Otter Creek improved overall stream physical-habitat conditions as represented by habitat score. However, only stream segments where there was natural riparian vegetative buffer or where stream buffers had been installed as a riparian BMP showed obvious improvement. Results also suggest that BMP implementation in Otter Creek substantially modified fish-community structure, but the overall community quality represented by IBI and percentage of intolerant individuals was not improved. The actual changes in the stream that are responsible for these changes in fish-community structure could be due to the observed habitat change, but available data do not allow for a cause-effect determination.

It is not fully understood why BMPs have improved habitat but have not improved fish communities in Otter Creek after more than five years of BMP implementation. One possible explanation is that streambank fencing and the regrowth of vegetation in the riparian areas at Otter Creek stations 1 and 3 have reduced bank erosion and narrowed and deepened the stream channel. This is evidenced by a decrease in the width to depth ratio and bank erosion (The coefficient $\beta 2$ is significant and $\beta 2<0$ for width to depth ratio and bank erosion in table 6). This channel morphological change further increases current velocity and, therefore, results in an increase in substrate size and a decrease in embeddedness. However, such habitat improvements have not been seen at the other stream sections that have no natural vegetative buffer or streambank fencing (for example, station 4). Even if sediment input from the watershed is reduced, the sediment accumulated inside the stream in the segment without riparian BMPs will continue to influence the habitat use by fishes in the improved stream sections; therefore, the overall process of improving fish community may take much longer than initially expected. It is apparent that more years and detailed environmental data would be necessary for causal inference of factors determining fish population levels and variability and for understanding the organizational mechanism of the stream system.

\section{Comparison of Results to Watershed Improvement Objectives}

In the Nonpoint Source Control Plan for the Sheboygan River Priority Watershed Project (Wisconsin Department of Natural Resources, 1993), the specific objectives for the Otter Creek subwatershed are the following:

1. Maintain the current forage fishery classification. Improve the physical and biological conditions of the stream to enhance the intolerant fishery and to meet the current biological use designation.

2. Protect endangered fish species.

3. Maintain recreational uses.

4. Protect and (or) enhance the quality of water delivered to the Sheboygan River.

5. Improve wildlife habitat.

Preliminary pollutant-reduction goals to help achieve these objectives were set at a 75-percent reduction of sediment loads and a 50-percent reduction of phosphorus loads. Data resulting from this project indicate that the water quality and habitat are improving, but detectable improvements in the fish populations were not observed. Estimates of the rainfall storm load reductions (tables 4 and 5), reductions in base-flow concentrations (table 2), and improvements in stream habitat (table 6) indicate that stream conditions overall have improved. Estimates of rainfall storm load reductions indicate that preliminary objectives set forth by the WDNR were realistic and that 
the final reductions came close to achieving these objectives. The level of BMP implementation was high for all types of targeted areas except upland BMPs and stream crossings. Considering that an estimated 97 percent of the total suspended solids that reaches Otter Creek originates from eroding cropland (Wisconsin Department of Natural Resources, 1993), additional upland BMP implementation could possibly reduce pollutant loads substantially more.

In comparison to specific objectives of the Nonpoint Source Control Plan, the success of the project in meeting each individual objective varied. Specific objectives are addressed as follows:

1. The current forage-fishery classification and biological use designation was maintained. Habitat was improved, but the intolerant fishery was not enhanced as measured by the number of intolerant species present.

2. Sampling during the course of the project did not show that the endangered species identified in the Nonpoint Source Control Plan (the striped shiner) was present at any of the sampling stations before or after installation of BMPs. A few of these species were identified at a sampling station in 1987 downstream from all of the sampling stations for this study. The 1987 sampling station was within less than 1,000 feet of the Sheboygan River. This sampling event was the reason that the nonpoint source control plan specifically identified the striped shiner as being resident in Otter Creek, but it has not been identified there since.

3. Recreational use was classified as partial body contact in the Nonpoint Source Control Plan, and this has not changed throughout the study period. Fishable numbers of warm water sport fish were not present before BMP implementation or during the post-BMP period.

4. The quality of water delivered to the Sheboygan River was shown to be improved except for the increase in fecal coliform concentrations, as shown by a decrease in concentrations of total suspended solids and $\mathrm{BOD}_{5}$ in base flow and a decrease in storm loads of total suspended solids, total phosphorus, and dissolved ammonia nitrogen from rainfall periods.

5. Habitat in the stream and riparian areas was improved.
In general, those objectives concerning water quality and habitat were met, and some of those concerning the Otter Creek fishery were met, but improvements in the fish communities were not observed.

\section{Summary and Conclusions}

The U.S. Geological Survey and the Wisconsin Department of Natural Resources began a comprehensive, multidisciplinary evaluation-monitoring program in 1989 to assess the effectiveness of best-management practices (BMPs) funded through the Wisconsin Nonpoint Source Program. Hydrologic, water-quality, habitat, and fish data were collected at Otter Creek from 1990 to 2002 with the pre-BMP period ending in September 1993 and the postBMP period beginning in October 1999. BMPs installed in this watershed included streambank protection and fencing, stream crossings, grade stabilization, buffer strips, various barnyard-runoff controls, nutrient management, and a small amount of upland BMPs.

Water-quality samples were collected during base flow for the entire study period and during storms for two periods, pre- and post-BMP implementation. Base-flow samples were analyzed for total suspended solids, total phosphorus, dissolved ammonia nitrogen, $\mathrm{BOD}_{5}$, and fecal coliform. Storm samples were analyzed for total suspended solids, total phosphorus, and dissolved ammonia nitrogen. Statistically significant differences between pre- and postBMP periods were detected in median concentrations of total suspended solids and $\mathrm{BOD}_{5}$ in base-flow samples but not total phosphorus or dissolved ammonia nitrogen; fecal coliform concentrations increased over the study period.

The median storm loads for total suspended solids, total phosphorus, and dissolved ammonia nitrogen during rainfall periods were compared statistically by means of the Wilcoxon rank-sum test. This test was also applied to regression residuals to test for differences between the pre- and post-BMP periods. Regression equations were constructed to remove some of the variability due to natural factors; a difference in the regression residuals is more likely to indicate a difference in water quality due to the BMPs than a test of differences using the raw storm-load data would have indicated.

Differences between the pre- and post-BMP storm loads from rainfall periods during the nonvegetative season were statistically significant at the 0.05 level for all three constituents monitored, as determined by changes in storm-load residuals from the regression equations. Although median storm loads from rainfall periods for 
the nonvegetative season were less during the post-BMP period than during the pre-BMP period, differences in storm-load residuals for this period did not prove to be statistically significant. When considering data from the entire year, changes in storm-load residuals were significant for two of the three water-quality constituents (total suspended solids and dissolved ammonia nitrogen).

The results from analysis of storm loads from rainfall periods suggest that the installation of BMPs was effective at reducing pollutant loads during the nonvegetative season, but conclusions could not be made about results from the vegetative season. This is not necessarily an indication that the BMPs are not effective during the vegetative season, but is more likely to be an artifact of the climatic and land-cover conditions during this period of the year.

Habitat and fish data were collected between July 30 and September 11 each year of the study to track the effects of BMPs on stream habitat and fish communities. Various habitat and fish characteristics were sampled or measured. These characteristics were used as variables to compute habitat-quality index scores and an index of biotic integrity (IBI). Final trend analysis using ANCOVA was done on the index scores, as well as some of the original variables to explore changes due to BMP implementation. Variability in both habitat and fish data was considerable. Habitat was improved for stream segments that had either natural riparian buffer or had streambank fencing installed, but not at the station where the riparian area was pasture and no streambank fencing was installed. The results also suggest that BMP implementation in Otter Creek substantially modified fish community structure, but the overall community quality represented by IBI and percentage of intolerant individuals was not improved.

\section{Acknowledgments}

Support for this study included contributions from the Wisconsin Department of Natural Resources, the U.S. Environmental Protection Agency, and the U.S. Geological Survey. The authors thank the staff at the Sheboygan County Land and Water Conservation Department who provided land-use data, communication with land owners, and input on the interpretation of final results. The authors also thank Troy Rutter and other colleagues at the U.S. Geological Survey and Wisconsin Department of Natural Resources for their work throughout the project.

\section{References Cited}

American Public Health Association, 1989, Standard methods for the examination of water and wastewater 17th edition: Washington, D.C., American Public Health Association [variously paginated].

American Public Health Association, 1992, Standard methods for the examination of water and wastewater 18th Edition: Washington, D.C., American Public Health Association [variously paginated].

Edwards, T.K., and Glysson, G.D., 1988, Field methods for measurement of fluvial sediment: U.S. Geological Survey Open-File Report 86-531, 118 p.

Engel, R.J., Roberts, B.A., and Steingraeber, J.A., 1978, Soil survey of Sheboygan County, Wisconsin: U.S. Department of Agriculture, Soil Conservation Service, $119 \mathrm{p}$.

Garn, H.S., Olson, D.L., and Ellefson, B.R., 2001, Water resources data Wisconsin, water year 2000: U.S. Geological Survey Water-Data Report WI-00-1, 560 p.

Grabow, G.L., Lombardo, L.A., Line, D.E., and Spooner, J., 1999, Detecting water quality improvement as BMP effectiveness changes over time-use of SAS for trend analysis: North Carolina State University Water Quality Group Newsletter ISSN 1062-9149, p. 1-8.

Graczyk, D.J., Walker, J.F., Horwatich, J.A., and Bannerman, R.T., 2003, Effects of best-management practices in the Black Earth Creek Priority Watershed, Wisconsin, 1984-1998: U.S. Geological Survey Water-Resources Investigations Report 03-4163, 24 p.

Helsel, D.R., and Hirsch, R.M., 1992, Statistical methods in water resources: New York, N.Y., Elsevier Science Publishing Company Inc., 522 p.

Holmstrom, B.K., Kammerer, P.A., Jr., and Erickson, R.M., 1992, Water resources data Wisconsin, water year 1991: U.S. Geological Survey Water-Data Report WI-91-1, 607 p.

Holmstrom, B.K., Kammerer, P.A., Jr., and Ellefson, B.R., 1993, Water resources data Wisconsin, water year 1992: U.S. Geological Survey Water-Data Report WI-92-1, $545 \mathrm{p}$.

Holmstrom, B.K., Kammerer, P.A., Jr., and Ellefson, B.R., 1994, Water resources data Wisconsin, water year 1993: U.S. Geological Survey Water-Data Report WI-93-1, $707 \mathrm{p}$. 
Holmstrom, B.K., Kammerer, P.A., Jr., and Ellefson, B.R., 1995, Water resources data Wisconsin, water year 1994: U.S. Geological Survey Water-Data Report WI-94-1, $645 \mathrm{p}$.

Holmstrom, B.K., Olson, D.L., and Ellefson, B.R., 1996, Water resources data Wisconsin, water year 1995: U.S. Geological Survey Water-Data Report WI-95-1, 562 p.

Holmstrom, B.K., Olson, D.L., and Ellefson, B.R., 1997, Water resources data Wisconsin, water year 1996: U.S. Geological Survey Water-Data Report WI-96-1, 464 p.

Holmstrom, B.K., Olson, D.L., and Ellefson, B.R., 1998, Water resources data Wisconsin, water year 1997: U.S. Geological Survey Water-Data Report WI-97-1, 506 p.

Holmstrom, B.K., Olson, D.L., and Ellefson, B.R., 1999, Water resources data Wisconsin, water year 1998: U.S. Geological Survey Water-Data Report WI-98-1, 508 p.

Holmstrom, B.K., Olson, D.L., and Ellefson, B.R., 2000, Water resources data Wisconsin, water year 1999: U.S. Geological Survey Water-Data Report WI-99-1, 578 p.

Lyons, J., 1992, The length of stream to sample with a towed electrofishing unit when fish species richness is estimated: North American Journal of Fisheries Management v. 12, p. 198-203.

Lyons, J., 1996, Patterns in the species composition of fish assemblages among Wisconsin streams: Environmental Biology of Fishes v. 45, p. 329-341.

Lyons, J., and Kanehl, P., 1993, A comparison of four electroshocking procedures for assessing the abundance of smallmouth bass in Wisconsin streams: St. Paul Minn., U.S. Department of Agriculture, Forest Service, North Central Forest Experiment Station, General Technical Report NC-159, 35 p.

National Oceanic and Atmospheric Administration, Climatological data annual summary, 2000, Wisconsin, v. 105, no. 13,27 p.

Porterfield, G., 1972, Computation of fluvial-sediment discharge: U.S. Geological Survey Techniques of WaterResources Investigations, book 3, chap. C2, 66 p.

Rantz S.E., and others, 1982, Measurement and computation of streamflow-v. 2, Computation of discharge: U.S. Geological Survey Water-Supply Paper 2175, p. 285-631.

Rappold, K.F., Wierl, J.A., and Amerson, F.U., 1997, Watershed characteristics and land management in the nonpoint source evaluation monitoring watersheds in Wisconsin: U.S. Geological Survey Open-File Report 97-119, $39 \mathrm{p}$.
SAS Institute Inc., 1990, SAS/STAT user's guide, version 6 (4th ed.), Cary, N.C., 2 v., 1,686 p.

Simonson, T.D., and Lyons, J., 1995, Comparison of catch per effort and removal procedures for sampling stream fish assemblages: North American Journal of Fisheries Management v. 15, p. 419-427.

Simonson, T.D., Lyons, J., and Kanehl, P.D., 1994, Guidelines for evaluating fish habitat in Wisconsin streams: St. Paul, Minn. U.S. Department of Agriculture, Forest Service, North Central Forest Experiment Station, General Technical Report NC-164.

Viessman, W.H., Knapp, J.W., Lewis, G.L., and Harbaugh, T.E., 1977, Introduction to hydrology, (2d ed): New York, Harper and Row Publishers Inc., 704 p.

Walker, J.F., 1993, Techniques for detecting effects of bestmanagement practices on stream-water chemistry: U.S. Geological Survey Open-File Report 93-130, 16 p.

Waschbusch, R.J., Olson, D.L., Ellefson, B.R., and Stark P.A., 2002, Water resources data Wisconsin, water year 2001: U.S. Geological Survey Water-Data Report WI-01-1, $610 \mathrm{p}$.

Waschbusch, R.J., Olson, D.L., Ellefson, B.R., and Stark P.A., 2003, Water resources data Wisconsin, water year 2002: U.S. Geological Survey Water-Data Report WI-02-1, $621 \mathrm{p}$.

White K.E., and Sloto R.A., 1990, Base-flow frequency characteristics of selected Pennsylvania streams: U.S. Geological Survey Water-Resources Investigations Report 90-4160, 67 p.

Wierl, J.A., Rappold, K.F., and Amerson, F.U., 1996, Summary of the land-use inventory for the nonpoint-source evaluation monitoring watersheds in Wisconsin: U.S. Geological Survey Open-File Report 96-123, 23 p.

Wischmeier, W.H., and Smith, D.D., 1978, Predicting rainfall erosion losses - a guide to conservation planning: U.S. Department of Agriculture Handbook, no. 537,58 p.

Wisconsin Department of Natural Resources, 1993, Nonpoint source control plan for the Sheboygan River Priority Watershed Project: Wisconsin Department of Natural Resources Publication WR-265-93 [variously paginated].

Wisconsin State Laboratory of Hygiene, 1992, Manual of analytical methods and quality assurance: Madison, Wis., University of Wisconsin, 330 p. 
8 Printed on recycled paper 